\title{
Community-Wide Zero Energy Ready Home Standard
}

A. Herk and T. Beggs IBACOS, Inc.

February 2016 


\section{NOTICE}

This report was prepared as an account of work sponsored by an agency of the United States government. Neither the United States government nor any agency thereof, nor any of their employees, subcontractors, or affiliated partners makes any warranty, express or implied, or assumes any legal liability or responsibility for the accuracy, completeness, or usefulness of any information, apparatus, product, or process disclosed, or represents that its use would not infringe privately owned rights. Reference herein to any specific commercial product, process, or service by trade name, trademark, manufacturer, or otherwise does not necessarily constitute or imply its endorsement, recommendation, or favoring by the United States government or any agency thereof. The views and opinions of authors expressed herein do not necessarily state or reflect those of the United States government or any agency thereof.

Available electronically at SciTech Connect http:/www.osti.gov/scitech

Available for a processing fee to U.S. Department of Energy and its contractors, in paper, from:

U.S. Department of Energy

Office of Scientific and Technical Information

P.O. Box 62

Oak Ridge, TN 37831-0062

OSTI http://www.osti.gov

Phone: 865.576 .8401

Fax: 865.576.5728

Email: reports@osti.gov

Available for sale to the public, in paper, from:

U.S. Department of Commerce

National Technical Information Service

5301 Shawnee Road

Alexandria, VA 22312

NTIS http://www.ntis.gov

Phone: 800.553 .6847 or 703.605 .6000

Fax: 703.605.6900

Email: orders@ntis.gov 


\title{
Community-Wide Zero Energy Ready Home Standard
}

\author{
Prepared for: \\ The National Renewable Energy Laboratory \\ On behalf of the U.S. Department of Energy's Building America Program \\ Office of Energy Efficiency and Renewable Energy \\ 15013 Denver West Parkway \\ Golden, CO 80401 \\ NREL Contract No. DE-AC36-08GO28308 \\ Prepared by: \\ A. Herk and T. Beggs \\ IBACOS, Inc. \\ 2214 Liberty Avenue \\ Pittsburgh, PA 15222 \\ NREL Technical Monitor: Stacey Rothgeb \\ Prepared under Subcontract No. KNDJ-0-40341-05
}

February 2016 
The work presented in this report does not represent performance of any product relative to regulated minimum efficiency requirements.

The laboratory and/or field sites used for this work are not certified rating test facilities. The conditions and methods under which products were characterized for this work differ from standard rating conditions, as described.

Because the methods and conditions differ, the reported results are not comparable to rated product performance and should only be used to estimate performance under the measured conditions. 


\section{Contents}

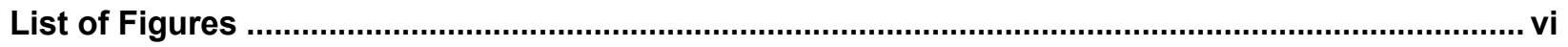

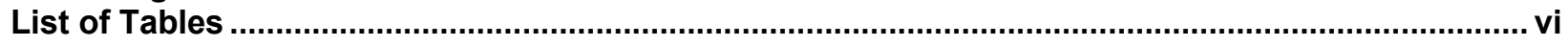

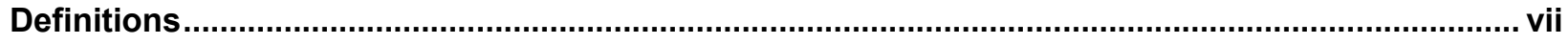

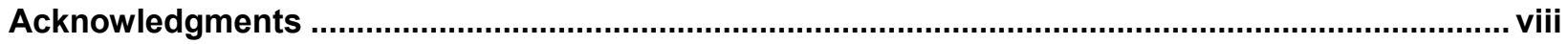

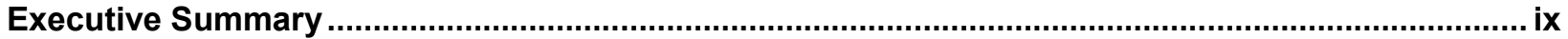

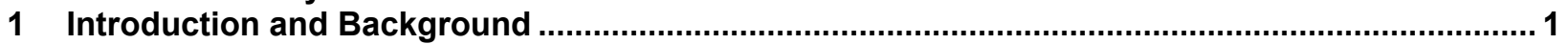

1.1 IBACOS's Community-Scale Performance Planning ............................................... 1

1.2 U.S. Department of Energy's Energy Efficiency Standard ..........................................

1.3 Stapleton's Energy-Efficiency Standards ...................................................................

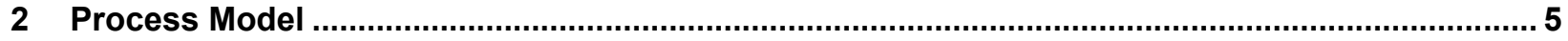

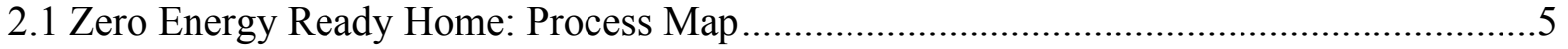

2.2 Zero Energy Ready Home: Team Members ....................................................................6

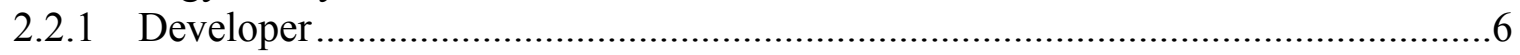

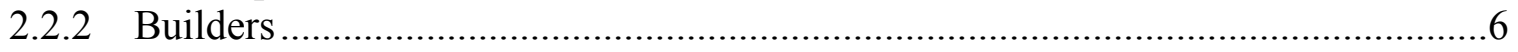

2.2.3 Zero Energy Ready Home Verifier...................................................................

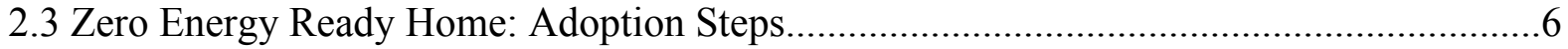

2.3.1 Verifier and Builder Group Meeting...........................................................6

2.3.2 Verifier and Builder Individual Meetings ........................................................6

2.4 Zero Energy Ready Home: Design ....................................................................... 7

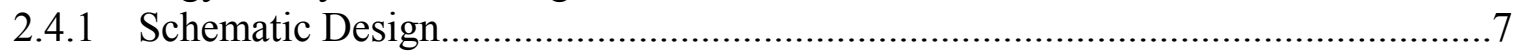

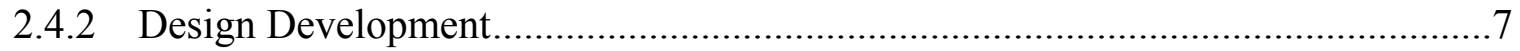

2.4.3 Construction Documentation .................................................................... 7

2.5 Zero Energy Ready Home: Postdesign ...................................................................8

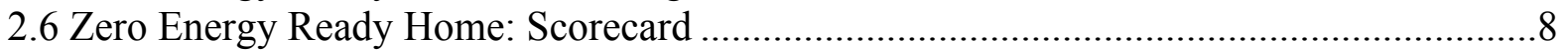

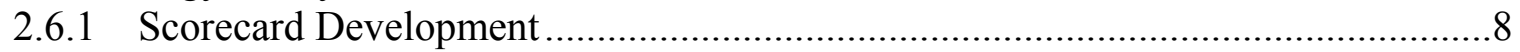

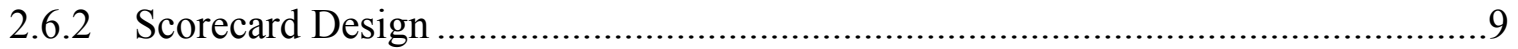

2.6.3 Scorecard Implementation .............................................................................. 10

2.7 Zero Energy Ready Home: Testing and Verification ............................................ 10

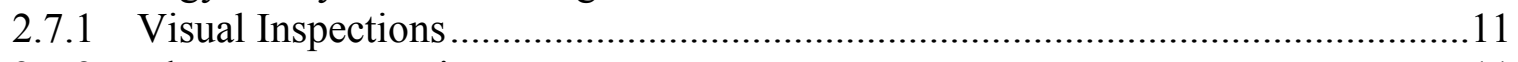

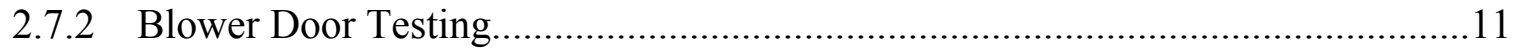

2.7.3 Duct Blaster Testing .................................................................................... 11

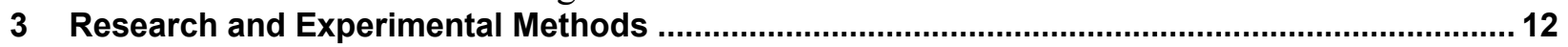

3.1 Zero Energy Ready Home at Stapleton: Process Map.................................................. 12

3.2 Zero Energy Ready Home at Stapleton: Team Members ............................................ 12

3.3 Zero Energy Ready Home at Stapleton: Verifier and Builder Meetings ..........................13

3.4 Zero Energy Ready Home at Stapleton: Design Review .............................................13

3.5 Zero Energy Ready Home at Stapleton: Scorecard Implementation ...............................13

3.6 Zero Energy Ready Home at Stapleton: Site Walk ................................................... 13

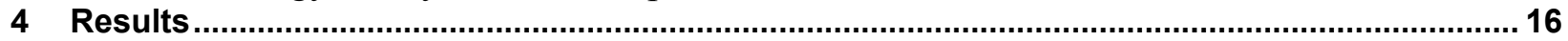

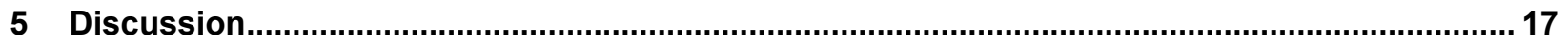

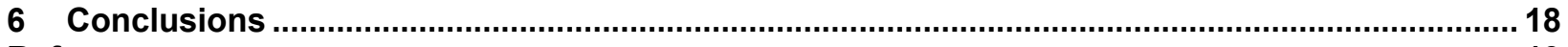

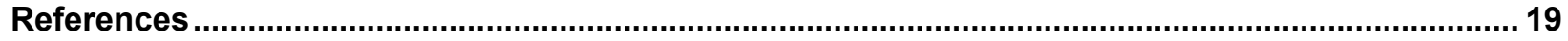

Appendix A: Full Zero Energy Ready Home Scorecard for a Stapleton Builder .............................. 21

Appendix B: U.S. Department of Energy Zero Energy Ready Home National Program

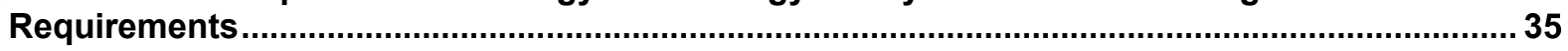

Appendix C: Example Zero Energy Ready Home Scorecard ...................................................... 45 


\section{List of Figures}

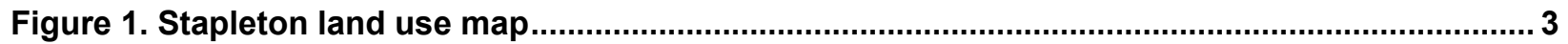

Figure 2. Example of a ZERH builder preparation timeline ................................................................ 5

Figure 3. Example of one section of a ZERH scorecard ................................................................. 10

Figure 4. Stapleton ZERH builder preparation timeline .............................................................. 12

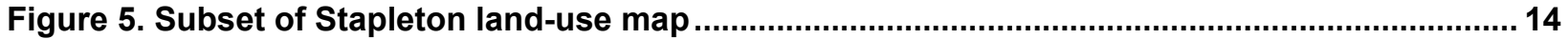

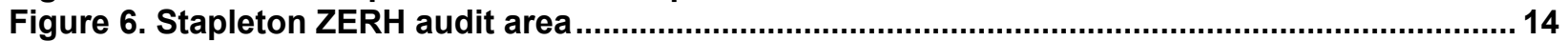

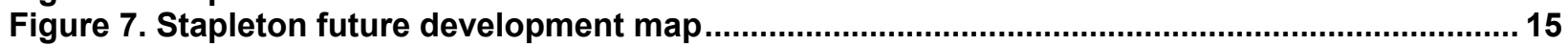

Figure 8. ZERH Stapleton builder scorecard summary ................................................................... 16

Unless otherwise noted, all figures and photos were created by IBACOS.

\section{List of Tables}

Table 1. DOE ZERH Requirements* 8

Table 2. DOE ZERH System Performance Targets*.

Unless otherwise noted, all tables were created by IBACOS. 


\section{Definitions}

DOE

EPA

ZERH
U.S. Department of Energy

Environmental Protection Agency

Zero Energy Ready Home 


\section{Acknowledgments}

The authors wish to acknowledge Forest City, the developer of the Stapleton community in Denver, Colorado, for its interest in the U.S. Department of Energy's Zero Energy Ready Homes program and for implementing the program in its communities. 


\section{Executive Summary}

This report outlines the steps a developer can take when creating and implementing highperformance standards such as the U.S. Department of Energy's (DOE's) Zero Energy Ready Home (ZERH) standards on a community-wide scale. The report also describes the specific examples of how this process is underway in the Stapleton community in Denver, Colorado, by the developer Forest City.

DOE's Building America research team IBACOS described a process for bringing the DOE ZERH standards to the Forest City Stapleton community, which is based on IBACOS's 15 years of community-scale development work. Through this work, the team gained an understanding of the various components a master developer needs to consider and created strategies for incorporating those components in the initial phases of development to achieve buildings that have higher energy performance than typical homes in the community.

A commitment to high-performance housing requires the developer to create the following:

- A set of performance standards that all builders in the community must meet

- A support and implementation strategy that clearly defines the roles and responsibilities of the developer and the builder

- A compliance verification plan.

An automated scoring system can be used to perform an internal audit that provides a detailed and consistent evaluation of how several homes under construction or builders' floor plans compare with the requirements of the DOE ZERH program. This audit can be performed multiple times at specific milestones during construction to allow the builder to make changes as needed throughout construction for the project to meet ZERH standards. This scoring system also can be used to analyze a builder's current construction practices and design. The audit score and comments then can be provided to the builders to encourage changes in future construction practices that will improve their products and help them to meet ZERH standards. 


\section{Introduction and Background}

In a master-planned community, a master developer acquires control of a large piece of land and develops a comprehensive plan for that land. It typically includes a wide mix of uses but may be limited to a single use (e.g., residential). However, each use comprises a wide range of building types (e.g., apartments, multifamily for-sale units, townhomes, live/work units, and various sizes of single-family detached housing). These developments typically have a few things in common:

- The master developer solicits a variety of builders to participate in the project once plan approvals have been granted; the master developer may reserve the right to act as a builder for one or more planned buildings.

- A set of architectural standards and a variety of other restrictive covenants are put in place to ensure the project builds out in line with the developer's vision and the approved plan. In this role, the developer is looking primarily at the sale of land to generate value for the project.

- These master-planned communities seek to create a diverse — and to some extent selfcontained-entity.

Stapleton is a leading-edge community that is being built by developer Forest City near Denver, Colorado, and has 2,935 developable acres in 7.5 square miles. Stapleton has consistently focused on energy efficiency and has kept up with the changes and improvements to highperformance building standards.

\subsection{IBACOS's Community-Scale Performance Planning}

The success of IBACOS's work (Prahl 2001) has shown — through mapping of builders' business processes - that a benchmark level of execution must be met before a builder can enter the highperformance building market. If a commitment to high-performance housing is to be achieved at a community scale, a developer needs to consider the following primary areas:

- The creation of a set of performance standards that all builders must meet

- A support and implementation strategy that clearly defines the roles and responsibilities of the developer and the builder

- A compliance verification plan that determines

- How much information the developer will obtain from the builders in demonstrating compliance

- When that information will be obtained

- Who will do the verification.

The U.S. Department of Energy's (DOE’s) Zero Energy Ready Home (ZERH) program establishes the performance criteria and verification protocols and leaves the developer to establish the support and implementation strategies.

DOE's Building America research team IBACOS has worked with master plan developers on projects such as the Summerset at Frick Park community in Pittsburgh, Pennsylvania (Prahl and Newhouse 2003), and the Community of Civano in Tucson, Arizona (Civano 2002). Summerset 
at Frick Park is a redeveloped brownfield site and a master-planned community with more than 700 variously sized single-family and multifamily homes. The developer implemented its vision of high-quality and high-performance housing in the early planning of that community. To achieve that goal, the developer worked with IBACOS to create a set of housing performance standards that all builders in the community had to follow; the intent was to guide builders and tradespeople through the required specifications and construction details. These standards defined the level of quality to be achieved in all the housing and covered topic areas such as improved energy performance, detailing for moisture control and long-term durability, and provisions to achieve and maintain good indoor air quality. IBACOS also worked with the developer to create training sessions, provide support for each builder, and develop a compliance verification plan. IBACOS also inspected and tested almost all the homes that were completed during the first phase of construction.

The Community of Civano was one of the first in the country to attempt to manage highperformance construction by several builders - each of which used different technologies. When the developer announced this land would be put up for auction, the City of Tucson (2003) developed an Integrated Method of Performance and Cost Tracking system document that outlined the goals for the land. The development team wanted to create a sustainable community in which conventional and alternative building materials could be used and in which mixed-use and neotraditional land planning could embody the goals of the Integrated Method of Performance and Cost Tracking system. The team referenced the requirements of the Sustainable Energy Standard, which were enforced at the time as a basis for the homes' energy performance. This standard reduced overall heating, cooling, and domestic hot water consumption by $50 \%$ and included the beneficial use of solar energy in all homes. To help the developers reach these goals, IBACOS led group training and provided individual support to the initial round of builders. This support included helping the builders during the design phase to perform energy analyses on their homes, conducting field training for the builders and their tradespeople, making follow-up field visits during construction, and some testing of homes to verify the energy performance goals were achieved.

\subsection{U.S. Department of Energy's Energy Efficiency Standard}

Since 2008, the DOE Builders Challenge program has been developing standards for building to energy-efficient performance levels. The DOE Challenge Home program included high standards for energy savings, comfort, health, and durability. This program has since been modified and now is called the DOE Zero Energy Ready Home program. All DOE ZERHs are verified by a qualified third party (a verifier), are at least $40 \%-50 \%$ more energy efficient than a typical new home, and generally correspond to a Home Energy Rating System Index score in the low to mid-50s according to DOE (n.d.).

Builders may choose the prescriptive path and have all the ZERH program requirements verified by a certified verifier, or they may follow the performance path and qualify their homes with REM/Rate Version 14 (AEC 2014) or EnergyGauge USA 3.1.00 software (EnergyGauge 2013), or both. 


\subsection{Stapleton's Energy-Efficiency Standards}

Forest City was selected as the master planner and developer for Stapleton in fall 1998. In 2001, Forest City closed on $\$ 145$ million in public financing and started construction. The first residents moved into Stapleton during June 2002. By December 2014, more than 5,600 homes had been completed for more than 19,000 residents. Figure 1 shows a plan for how Forest City divided the land and the state of development as of fall 2014. In 2015, the IBACOS team started to create a master plan for developer Forest City for creating high-performance homes for the Stapleton community in Denver, Colorado.

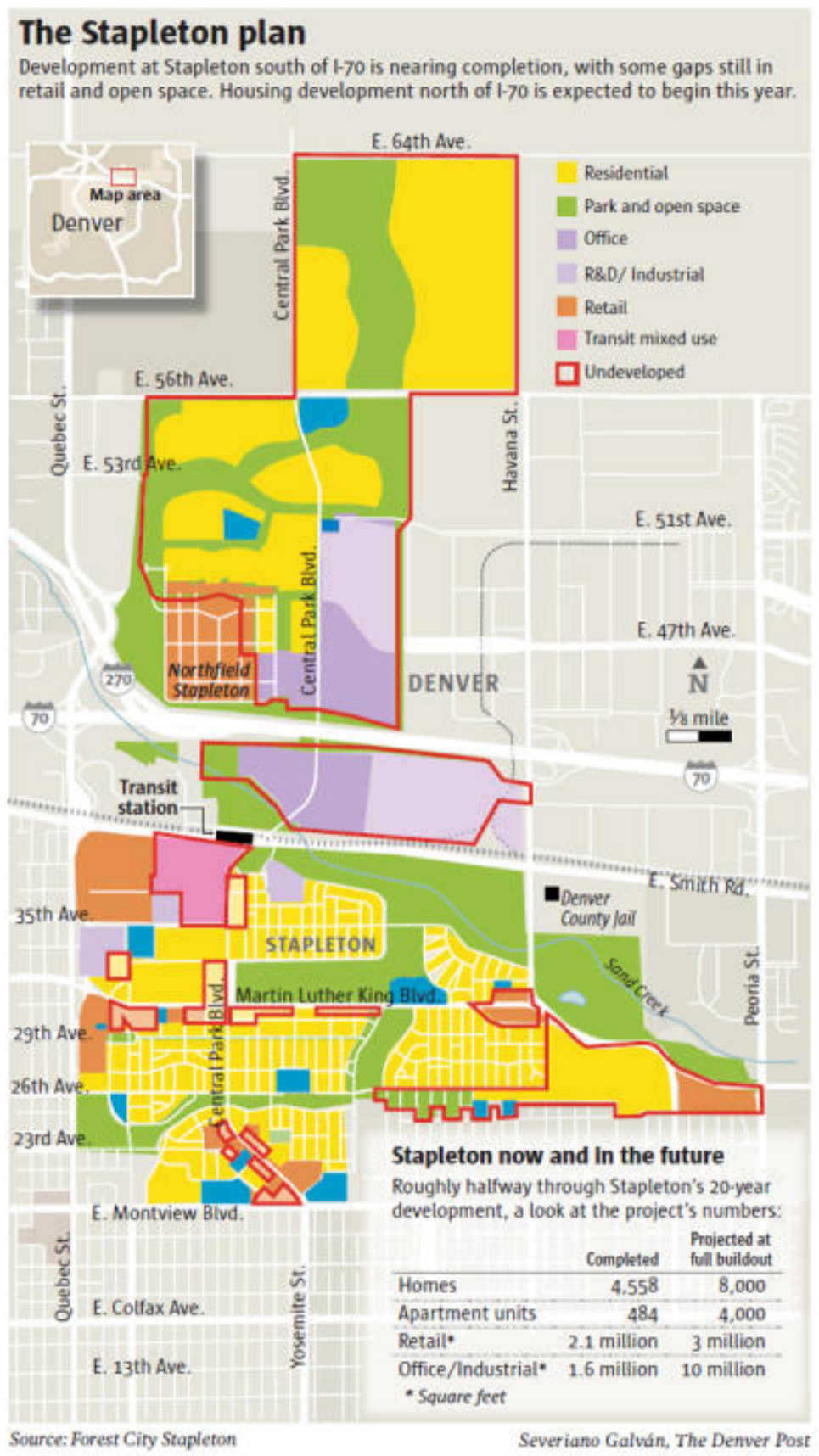

Figure 1. Stapleton land use map 
The Stapleton community first followed the standards set by the Built Green Colorado program (Built Green 2014), which is administered under the Home Builders Association of Metro Denver and is one of the oldest and largest green home building programs in the United States. This program encourages home builders to use sustainable and energy-efficient practices and technologies to create homes that are better built to the environment.

Stapleton subsequently raised its building standard to ENERGY STAR ${ }^{\circledR}$ Version 1 and then to Version 2 and Version 3 as those were released. Built Green-certified homes are required to be at least $15 \%$ more energy efficient than homes built to the 2006 International Energy Conservation Code (ICC 2006), whereas ENERGY STAR Version 3 homes are required to be at least 20\% more efficient than those built under the International Energy Conservation Code (ICC 2009). ENERGY STAR Version 1, which is administered under the Environmental Protection Agency (EPA), was released in 1995 and focused on certain key areas for improvement. The releases of ENERGY STAR Version 2 in 2006 and Version 3 in 2011 included more stringent performance guidelines. Today, $100 \%$ of the homes in Stapleton are ENERGY STAR certified; it is the largest ENERGY STAR community in Colorado.

Since 2014, Forest City has chosen to create a program to build according to the ZERH standard in the Stapleton community. IBACOS has worked with the developer to implement and support the ZERH program. In the preliminary stages of development for ZERH implementation, Stapleton is coordinating and facilitating the training, evaluation, and support of builders to meet the initial standards and to identify gaps in moving to the next standard and then training around those gaps. As local resources (e.g., knowledgeable raters and utility program support) have become more prevalent, developers can tap into those as resources to assist builders. 


\section{Process Model}

IBACOS created a ZERH community-wide implementation process model as an example of how a developer should approach integrating high-performance solutions into the housing products builders in their communities build. This report also looks at the model and how it applies to the Stapleton area for ZERH standards. This model references the ZERH National Program Requirements (Revision 04) in effect at the time of the work (DOE 2014). The ZERH standards will undergo regular updates and should be referenced with each project to use the most up-todate information and requirements.

\subsection{Zero Energy Ready Home: Process Map}

The process for having an entire community successfully accept ZERH as a building standard depends on the team working collaboratively as a unit and on a well-developed plan for implementation. Figure 2 shows a timeline a new development might follow to successfully implement the ZERH process as a standard for its community.

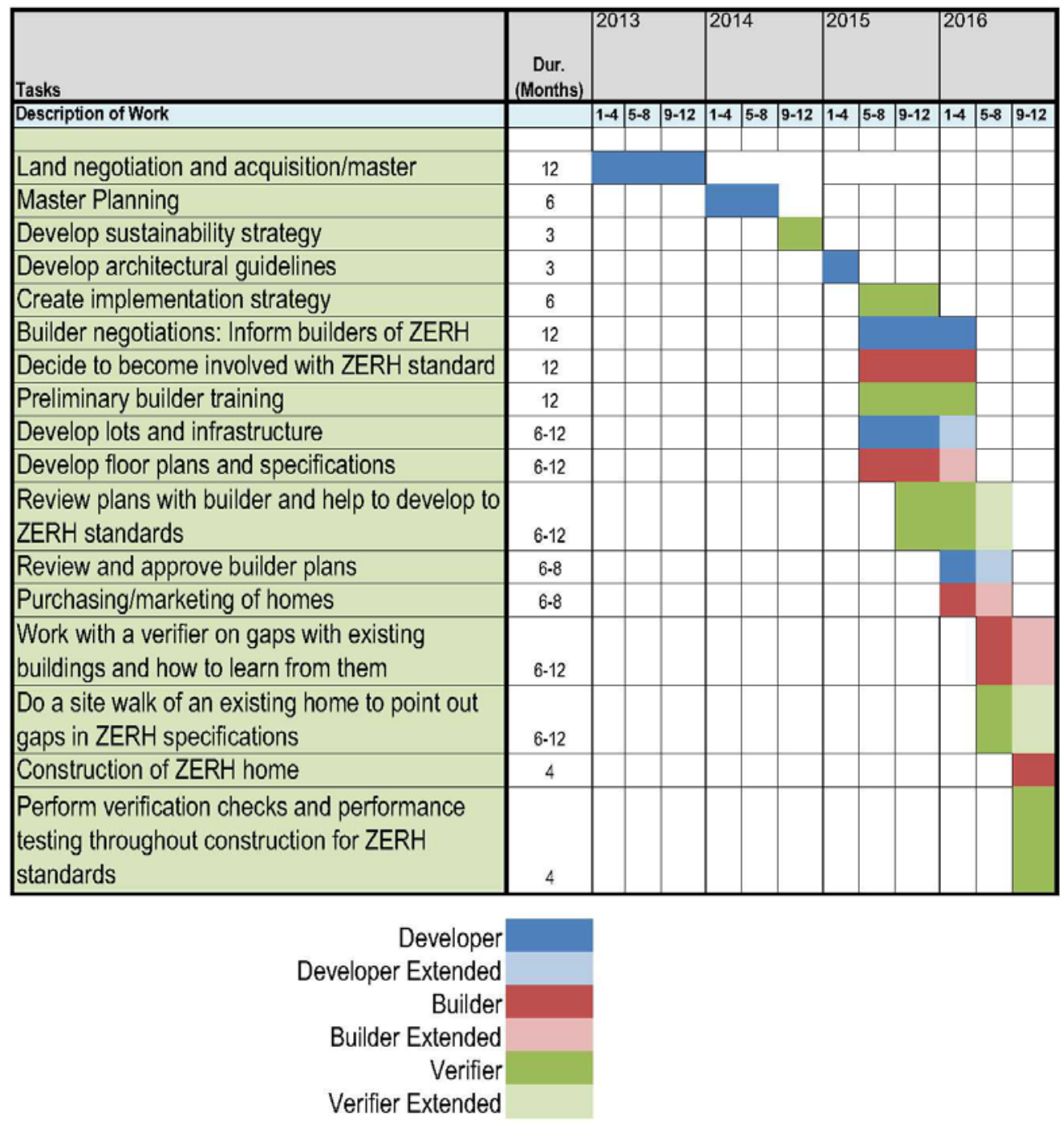

Figure 2. Example of a ZERH builder preparation timeline 


\subsection{Zero Energy Ready Home: Team Members}

The success of the ZERH baseline depends on the level of cooperation from many participants, including the developer, the builders, the ZERH raters, and the energy verifier. The following discussion describes the primary roles of the ZERH team members.

\subsubsection{Developer}

In adopting the ZERH standards for a community, the developer acts as the common link between the verifier and the builders of that community. The developer should designate a single person to guide the development and to oversee the implementation of the ZERH performance standards. The Stapleton developer, Forest City, was very interested in developing the Stapleton area to ZERH standards.

\subsubsection{Builders}

The project requires, from the beginning, a high level of cooperation between the builders and the developer and complete buy-in into the ZERH performance standards. A builder needs to provide a thorough design with all performance specifications for the developer and verifier to review for compliance. If a builder is unwilling to modify its current product design or to create a new ZERH-specific design, the ZERH effort likely will fail.

\subsubsection{Zero Energy Ready Home Verifier}

The verifier is involved through all aspects of a ZERH program and is integral to its success. The developer should carefully choose an appropriately qualified verifier, particularly at the scale of a master-planned community. The scale of the project contributes to the level of experience the verifier needs to effectively manage the project and ensure the necessary quality. Also, the developer should research its options for a verifier to ensure the necessary skills and experience are available to achieve success for the scope and goals of the project.

The verifier selects options for reaching ZERH energy performance targets and protocols, calculates baseline energy consumption, and presents comparisons of the options to the builder. The verifier also models the calculated energy savings and ensures the as-built conditions meet the specification. A single verifier may be used for the whole development, or an individual verifier can be used for each builder.

\subsection{Zero Energy Ready Home: Adoption Steps}

A multistep process is required to ensure the builders successfully adopt the ZERH standard.

\subsubsection{Verifier and Builder Group Meeting}

Once the developer has chosen the builders and those builders have accepted the challenge, the ZERH verifier will meet with the builders from the community. This is a general introduction of who the verifier is, what the verifier plans to do with the builders, and how the verifier plans to help the builders. The verifier can explain the overall concept of ZERH standards to the builders as a whole but should meet individually with each builder to further discuss the ZERH requirements as they relate to that builder's homes.

\subsubsection{Verifier and Builder Individual Meetings}

During each meeting, the builder and verifier will talk through the ZERH standards to develop an understanding of where the builder stands on meeting those standards. This helps the builder and 
verifier grasp the builder's gaps and barriers to achieving ZERH standards in that builder's product.

\subsection{Zero Energy Ready Home: Design}

When a builder is developing new floor plans to align with the ZERH standard, the verifier needs to review the floor plans for gaps and barriers to achieving the ZERH standards. Early involvement of the verifier allows the verifier and builder to ensure compliance through the design process. If existing plans are to be used, as was the case in Stapleton, the verifier and builder will need to review those designs as they relate to ZERH compliance.

During the design process, the designs and compliance intent must be communicated from the builder to the developer. This can be done as part of the design review process with the verifier. At this stage, iterative solutions that require refining the design of the house may need to be implemented. At minimum, IBACOS recommends that the following activities take place during the design phases to develop and document compliance with energy performance standards to the developer: Schematic Design, Design Development, and Construction Documentation.

\subsubsection{Schematic Design}

At this stage, the builder and verifier can review the configuration of the proposed home, particularly the floor plan, volume, and approximate quantity and distribution of glazing. Basic building shell energy modeling should be performed to evaluate the gross energy and thermal performance. Modeling techniques are useful in guiding early design decisions that involve, for example, hot water distribution system layouts, trade-offs between costs and energy savings, building durability issues, and systems integration. For example, THERM software (LBNL 2014) may be used to evaluate the potential for condensation in a standard wall assembly, or WUFI software (Fraunhofer 2015) could be used to evaluate the drying potential of a proposed wall. Simulation-based decision making can enhance and integrate home designs to allow them to perform better against quality and energy-efficiency measures. It also can clearly demonstrate that a design is heading toward meeting the ZERH program requirements.

\subsubsection{Design Development}

During this period, the builder and verifier should meet to ensure ZERH compliance in design as the final decisions are being made regarding the floor plan, elevation, and section drawings. These plans will include integrated mechanical and structural systems and interaction with plumbing, as well as vertical and horizontal ductwork layouts. Detailed discussions about the insulation system package and window specifications should be held at this time. The verifier will perform specific and detailed energy modeling on the shell to verify the house is in compliance with ZERH standards and to check the Home Energy Rating System score.

\subsubsection{Construction Documentation}

During this phase, the builder and verifier will meet again before the plans are finalized for construction. The builder should be able to provide a complete compliance strategy to the developer. Construction documents must specify and indicate the insulation, air sealing, and mechanical and other systems or details that are necessary to comply with the ZERH performance standards. The verifier will supply final energy modeling results that demonstrate compliance with ZERH standards. 


\subsection{Zero Energy Ready Home: Post-Design}

When the verifier becomes involved after the builders have already designed the product, as was the case with Stapleton, the verifier will need to review the plans as designed for gaps and barriers to the ZERH standards. All floor plans and mechanical information need to be gathered from the builder and, if necessary, from the tradespeople to verify ZERH standard compliance. Some modifications to the design will probably be needed at this stage.

\subsection{Zero Energy Ready Home: Scorecard}

Understanding the builders' baseline status with respect to the ZERH standard is significant to bringing the builders' specifications up to the performance level of the ZERH standards. The information can be organized in any one of numerous ways, but a checklist must be developed to evaluate all areas of the ZERH standards. This section describes the method IBACOS developed for verifiers to help builders achieve the ZERH standards.

\subsubsection{Scorecard Development}

To help enable builders to build to ZERH standards and to help ZERH verifiers analyze where the builders initially stand with regard to meeting the ZERH standards, IBACOS reviewed the DOE ZERH National Program Requirements (Revision 04) (DOE 2014) and created a scorecard to be used while reviewing floor plans and walking the building site. A verifier could use this scorecard to compare current specifications to each item in the ZERH program checklist. Appendix A contains the full scorecard for reference. The scorecard touches on each major component of the ZERH requirements on a 0/1 pass/fail basis. Table 1 shows the basic requirements for meeting $\mathrm{ZERH}$ as stated by DOE.

Table 1. DOE ZERH Requirements*

\begin{tabular}{|c|c|}
\hline $\begin{array}{c}\text { Area of } \\
\text { Improvement }\end{array}$ & Requirement \\
\hline $\begin{array}{l}\text { ENERGY STAR } \\
\text { for Homes Baseline }\end{array}$ & Certified under ENERGY STAR Qualified Homes Version 3. \\
\hline Envelope & $\begin{array}{l}\text { Fenestration to meet or exceed the latest ENERGY STAR requirements. } \\
\text { Ceiling, wall, floor, and slab insulation to meet or exceed the } 2012 \\
\text { International Energy Conservation Code (ICC 2012) levels. }\end{array}$ \\
\hline Duct System & Ducts to be located within the home's thermal and air barrier boundary. \\
\hline Water Efficiency & Hot water delivery systems to meet efficient design requirements. \\
\hline $\begin{array}{l}\text { Lighting and } \\
\text { Appliances }\end{array}$ & $\begin{array}{l}\text { All installed refrigerators, dishwashers, and clothes washers to be } \\
\text { ENERGY STAR qualified. } \\
\text { 80\% of lighting fixtures to be ENERGY STAR qualified or ENERGY } \\
\text { STAR lamps (bulbs) in a minimum } 80 \% \text { of sockets. } \\
\text { All installed bathroom ventilation and ceiling fans to be ENERGY } \\
\text { STAR qualified. }\end{array}$ \\
\hline Indoor Air Quality & Certified under EPA Indoor airPLUS (EPA 2014a). \\
\hline Renewable Ready & $\begin{array}{l}\text { Comply with the Consolidated Renewable Energy Ready Home } \\
\text { Checklist (EPA 2014b). }\end{array}$ \\
\hline
\end{tabular}

In the ZERH standard, each area of improvement also has footnotes and additional information to explain the respective requirements. The ZERH National Program Requirements also list information for heating, ventilating, and air-conditioning equipment and windows (Table 2). 
Requirements are also included for insulation, infiltration, water heaters, thermostats, and lighting, which were reflected in the ZERH scorecard that IBACOS created. Appendix B provides the full DOE ZERH National Program Requirements.

Table 2. DOE ZERH System Performance Targets*

\begin{tabular}{c|c|c|c}
\hline & Hot Climates & Mixed Climates & Cold Climates \\
\hline \multicolumn{3}{|c|}{ Heating, Ventilating, and Air-Conditioning Equipment Requirement } \\
\hline Annual Fuel Utilization Efficiency & $80 \%$ & $90 \%$ & $94 \%$ \\
\hline Seasonal Energy Efficiency Ratio & 18 & 15 & 13 \\
\hline Heating Seasonal Performance Factor & 8.2 & 9 & 10 \\
\hline \multicolumn{4}{|c|}{ Windows } \\
\hline Solar Heat Gain Coefficient & 0.25 & 0.27 & any \\
\hline U-Value & 0.4 & 0.3 & 0.27 \\
\hline
\end{tabular}

*See the DOE ZERH Program Requirements (Revision 04) (DOE 2014) for more information.

The most current ZERH standard should be checked against this document because the standard will undergo regular revisions. This report is intended as a guide for interpreting the most current ZERH National Program Requirements.

\subsubsection{Scorecard Design}

To create a scorecard for review of a builder's product against the ZERH program requirements, IBACOS used seven basic areas for improvement to develop areas of verification:

- ENERGY STAR (as a baseline)

- Building envelope

- Duct system

- Water efficiency

- Lighting and appliances

- Indoor air quality

- Renewable ready.

IBACOS analyzed each area of improvement within the ZERH program requirements, including the associated footnotes, and expanded those areas into checklist items on the scorecard. Figure 3 shows an example of one section for the scorecard, the lighting and appliances requirement. This figure shows several "subcategories" that coordinate with the ZERH requirements under the lighting and appliances category. For this example, these subcategories include appliances, lighting, and fans. The verifier selected 0 if the builder was not complying with this checklist item or 1 if the builder was complying. A comments section appeared in the scorecard for a " 0 " score to enable the verifier to add more details about why the builder was not complying with the checklist item or how the builder might be able to comply by making a few design changes. Appendix A shows an example of a full ZERH scorecard that IBACOS created for a Stapleton builder. 


\section{Lighting and Appliances}

\section{Appliances}

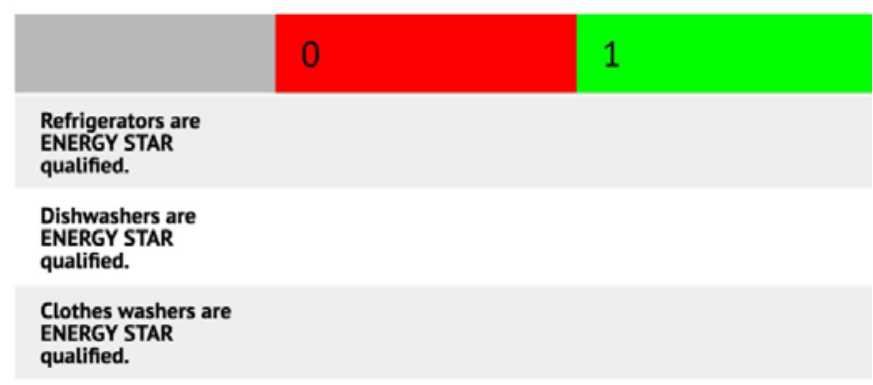

\section{Lighting}

ONE of the following is required.

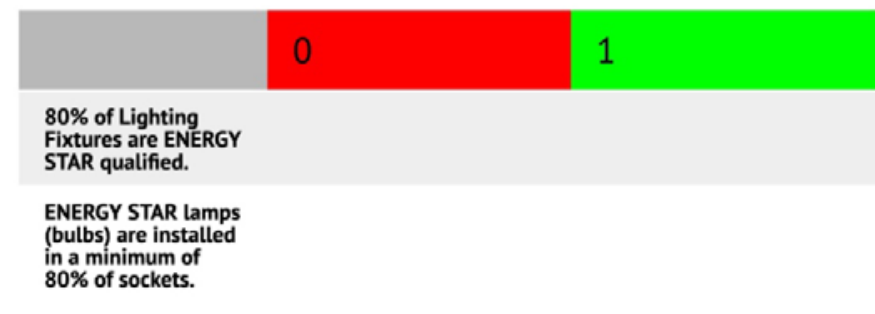

Fans

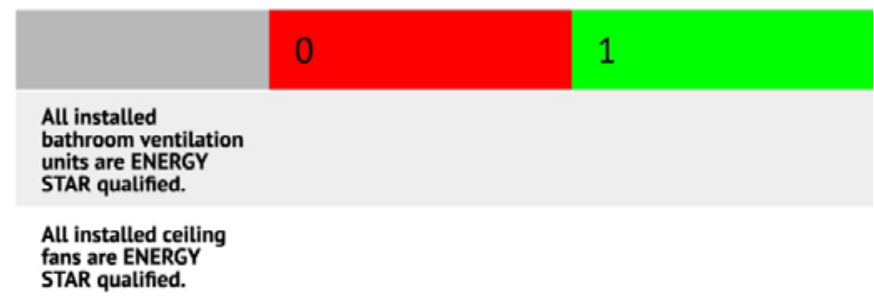

Figure 3. Example of one section of a ZERH scorecard

\subsubsection{Scorecard Implementation}

The verifier and local energy rater can walk the construction site of a development or community to check current building practices for a home that is under construction. The scorecard results can form the builder's baseline to determine where the product must improve to meet the ZERH requirements. The scorecard also can be used once ZERH production is underway to evaluate practices and ensure that ZERH standards are being maintained during the building process.

\subsection{Zero Energy Ready Home: Testing and Verification}

When the ZERH homes have entered production, the verifier will work with the builder during construction to ensure that the ZERH standards are being met, regardless of whether the builder is following the prescriptive path (i.e., having all ZERH requirements verified by a certified verifier) or the performance path (i.e., qualifying the homes by using REM/Rate Version 14 and/or EnergyGauge USA 3.1.00 software). 


\subsubsection{Visual Inspections}

Many of the DOE ZERH checklist items can be verified through simple visual inspections that can range from a single walk-through to ongoing field inspections at various stages of construction. In essence, a visual inspection is equivalent to a construction supervisor's daily duties: verifying that the tradespeople are installing their work properly. Typically a third party, such as a utility representative, code official, or home energy rater, also performs some visual inspections as a quality assurance check for the consumer.

The ZERH verification program checks the energy performance attributes of buildings with a minimum of two visual inspections; it is common to need more to provide a thorough examination. The first inspection takes place after the insulation has been installed in the home; it checks that the insulation levels are correct and that the insulation product has been installed properly. At this stage, a visual inspection of the air-sealing techniques also can be performed. A second visual inspection takes place once the home is in the final stages of completion. A blower door test also can be performed at this point.

It is important to note that at least two inspections are required for the verification process; house-specific inspection points beyond the insulation and final inspections may also be chosen. A few examples follow:

- Many regions build homes with basements; in this case, insulation that is installed below the foundation needs to be inspected before the slab is poured.

- Ducts can be inspected before walls are finished to allow the ducts to be sealed if the leakage rates are high.

- Testing may be conducted for duct leakage to the outside, which would be completed at the final inspection.

\subsubsection{Blower Door Testing}

A blower door is calibrated for testing air leakage rates of a building. During the final inspection, a verifier can perform blower door tests to measure the airtightness of the shell by depressurizing the envelope to a pressure difference of 50 Pascals between the indoors and the outdoors. The blower door test is typically performed during construction after the drywall has been installed but before the trim is hung. This is done so any additional air sealing that is required to bring the home into compliance can be done while the home is still at a fairly rough stage, as opposed to trying to caulk and seal around finish materials such as flooring, trim, and millwork.

\subsubsection{Duct Blaster Testing}

One important area to test in the home is the heating, ventilating, and air-conditioning system. Measuring the effectiveness and integrity of the duct system after mastic sealing indicates how much air is being supplied by the system to the intended rooms and how much air is going to other unintended places (e.g., cavities and attic). This testing should be done throughout construction and when construction is complete. A separate test can be completed to measure the duct leakage to the outside, which is an important consideration and a worst-case leakage path for the ductwork. Delivering conditioned air to the outdoors is counter to any energy-efficiency program. 


\section{Research and Experimental Methods}

The eight builders involved in building out the Stapleton area worked with IBACOS to understand where their products stand with regard to the ZERH specification. Under the process outlined in Section 2 of this report, the Stapleton development is onboarding builders and determining the work they need to do to comply with ZERH standards. Section 3.1 details the methods for baselining a builder to understand the gaps between what that builder is currently building in Stapleton and the ZERH requirements. This was done via a scorecard tool that was designed to measure those gaps and to target the necessary design updates.

\subsection{Zero Energy Ready Home at Stapleton: Process Map}

Stapleton had an early start on complying with the ZERH program because the builders in the community were already working within the parameters of ENERGY STAR Version 3; however, IBACOS specifically designed for Stapleton the process map shown in Figure 4 to help the builders there work through any remaining gaps.

\begin{tabular}{|c|c|c|c|c|c|c|c|c|c|c|}
\hline Tasks & \begin{tabular}{|c} 
Dur. \\
(Months) \\
\end{tabular} & 2013 & & 2014 & & 2015 & & & $\overline{16}$ & \\
\hline Description of Work & & $1-4 \mid 5-8$ & $9-12$ & \begin{tabular}{|l|l|}
$1-4$ & $5-8$ \\
\end{tabular} & $9-12$ & \begin{tabular}{|l|l|l|}
$1-4$ & $5-8$ \\
\end{tabular} & 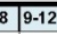 & & $5-8$ & $9-12$ \\
\hline Land negotiation and acquisition/master & 12 & & & & & & & & & \\
\hline Master Planning & 6 & & & & & & & & & \\
\hline Develop sustainability strategy & 3 & & & & & & & & & \\
\hline Develop architectural guidelines & 3 & & & & & & & & & \\
\hline Create implementation strategy & 6 & & & & & & & & & \\
\hline Builder negotiations: Inform builders of ZERH & 12 & & & & & & & & & \\
\hline Decide to become involved with ZERH standard & 12 & & & & & & & & & \\
\hline Preliminary builder training & 12 & & & & & & & & & \\
\hline Develop lots and infrastructure & $6-12$ & & & & & & & & & \\
\hline Develop floor plans and specifications & $6-12$ & & & & & & & & & \\
\hline $\begin{array}{l}\text { Review plans with builder and help to develop to } \\
\text { ZERH standards }\end{array}$ & $6-12$ & & & & & & & & & \\
\hline Review and approve builder plans & $6-8$ & & & & & & & & & \\
\hline Purchasing/marketing of homes & $6-8$ & & & & & & & & & \\
\hline $\begin{array}{l}\text { Work with a verifier on gaps with existing } \\
\text { buildings and how to learn from them }\end{array}$ & $6-12$ & & & & & & & & & \\
\hline $\begin{array}{l}\text { Do a site walk of an existing home to point out } \\
\text { gaps in ZERH specifications }\end{array}$ & $6-12$ & & & & & & & & & \\
\hline Construction of ZERH home & 4 & & & & & & & & & \\
\hline $\begin{array}{l}\text { Pertorm veritication checks and pertormance } \\
\text { testing throughout construction for ZERH }\end{array}$ & 4 & & & & & & & & & \\
\hline
\end{tabular}

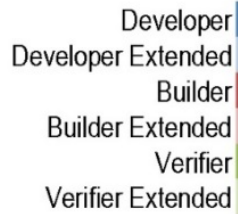

Figure 4. Stapleton ZERH builder preparation timeline

\subsection{Zero Energy Ready Home at Stapleton: Team Members}

As stated in Section 2, the success of ZERH as a standard in a community depends on the level of cooperation from many participants. At Stapleton, the team began with the Stapleton developer, Forest City, which was very interested in developing the Stapleton area to ZERH standards. The builders and the developer already had a relationship at Stapleton, and the builders were informed that they would be required to build to ZERH standards by 2016. Also, each builder hired and used multiple energy raters. This added a level of complexity to the standards adoption process. IBACOS worked closely with the developer and the energy raters to define a process to help the builders achieve the ZERH standard by 2016. 


\subsection{Zero Energy Ready Home at Stapleton: Verifier and Builder Meetings}

The builders in Stapleton were made aware that their products must meet ZERH standards by 2016 to continue building in new phases of development in the Stapleton area. IBACOS met with each builder and energy verifier to review any of the builder's initial questions and concerns about ensuring its product could achieve ZERH standards. The ZERH adoption process for IBACOS with the Stapleton builders and developer began with the preliminary builder training in mid-2015 (Figure 4).

\subsection{Zero Energy Ready Home at Stapleton: Design Review}

Most of the Stapleton builders were already building house products at the time IBACOS first became involved in mid-2014. They also had ideas about the floor plans they might use in the new development area to comply with the ZERH standards. IBACOS reviewed those house plans for gaps in achieving the ZERH standards and made suggestions for modifications to help the builders throughout the process.

\subsection{Zero Energy Ready Home at Stapleton: Scorecard Implementation}

IBACOS used the scorecard to analyze the level to which the eight builders at Stapleton were building in the third quarter of 2014. IBACOS and the energy rater for each builder compared the current specifications of its built products to each item in the ZERH program scorecard.

\subsection{Zero Energy Ready Home at Stapleton: Site Walk}

IBACOS and the local energy rater walked through several homes in production to complete a ZERH compliance scorecard for each of the eight builders. This exercise identified many areas of compliance within each builder's specifications, along with areas that needed to be addressed to meet the ZERH standards. Figure 5 shows a small section of the Stapleton area and the use of the land in this area. Figure 6 shows the layout of the Stapleton area where IBACOS and the local energy rater walked during the third quarter of 2014.

Figure 7 shows the area of the site walk in yellow within the context of the future development area, which is shown in red. By the fourth quarter of 2016, this future development area should be under development with homes that fully meet ZERH standards. 


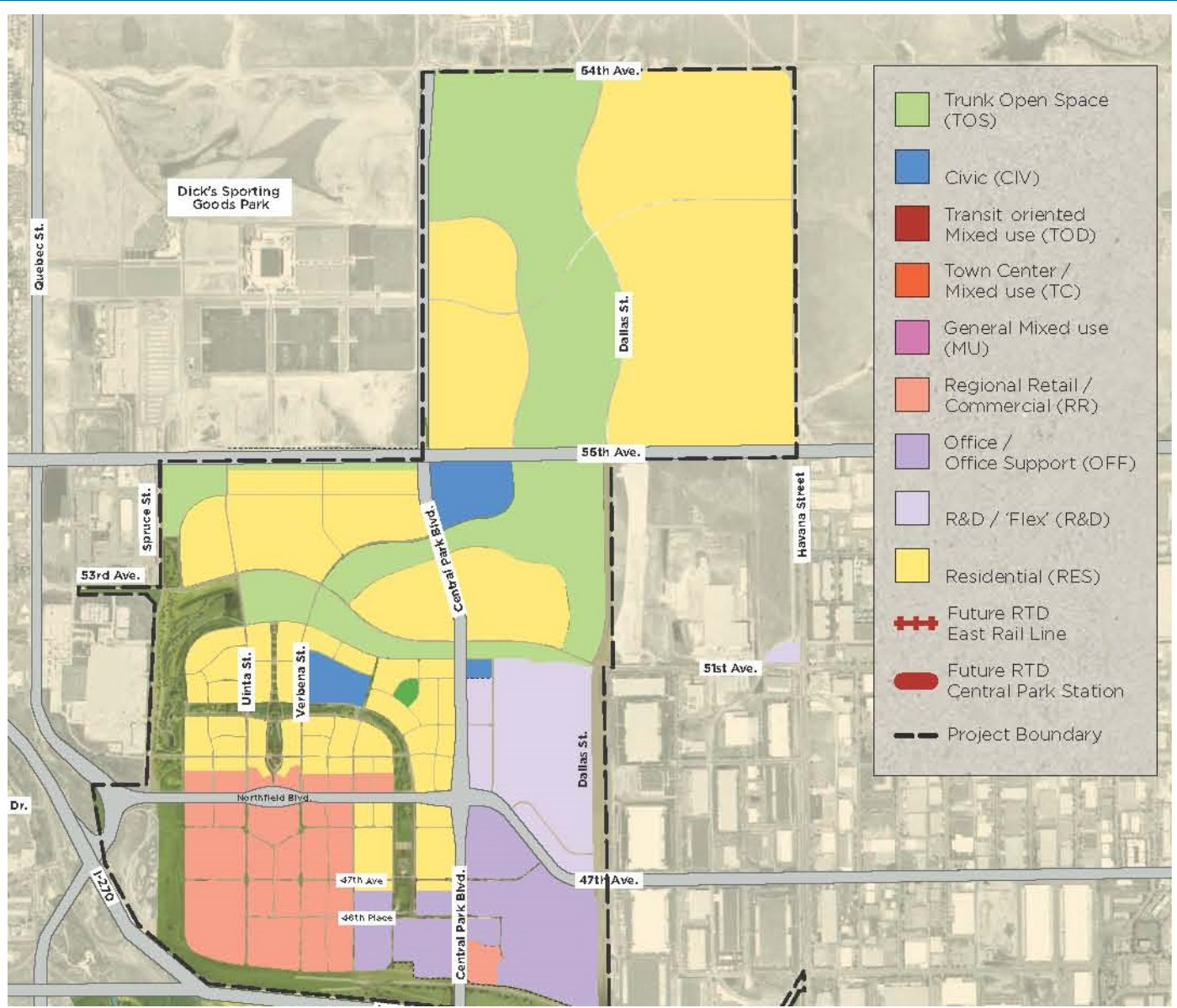

Figure 5. Subset of Stapleton land-use map

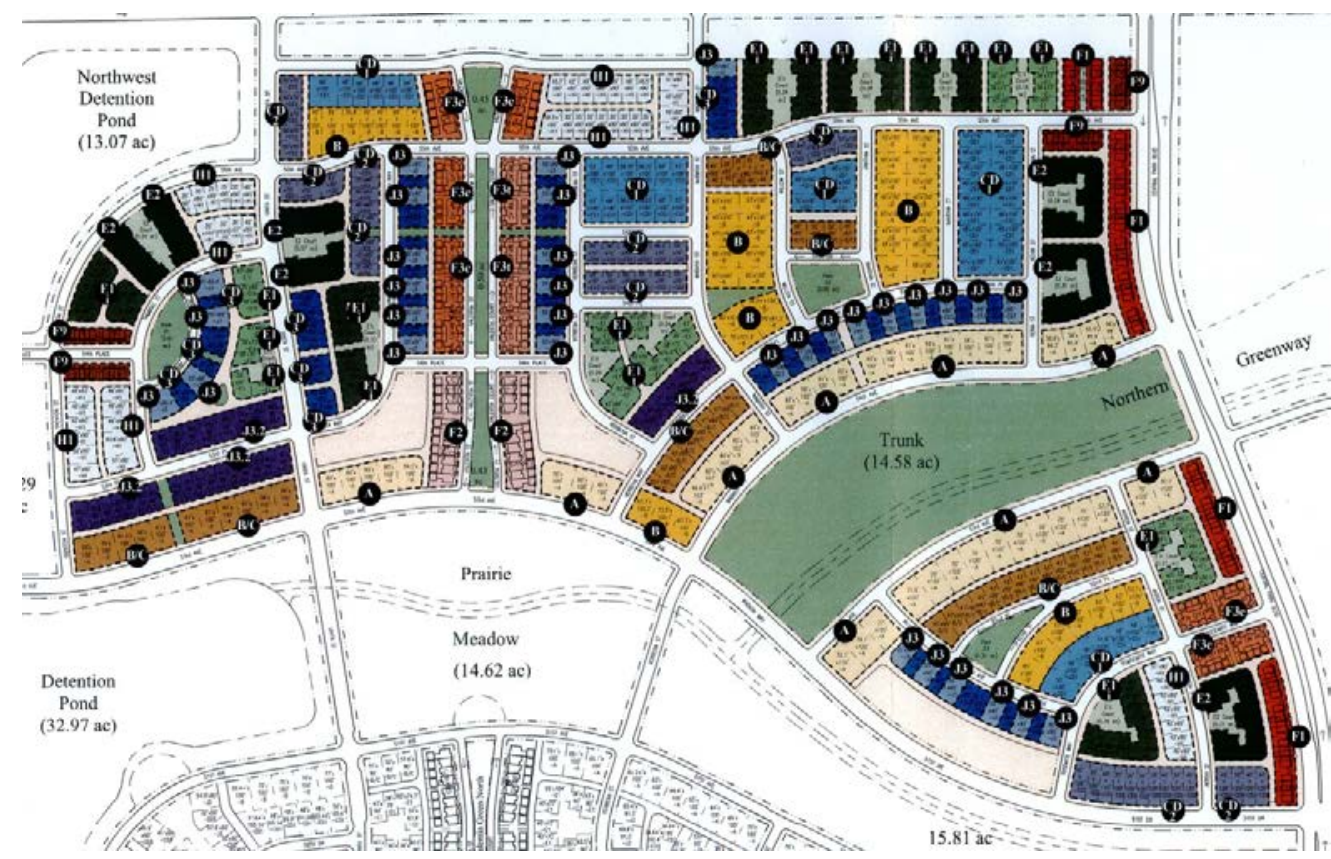

Figure 6. Stapleton ZERH audit area 


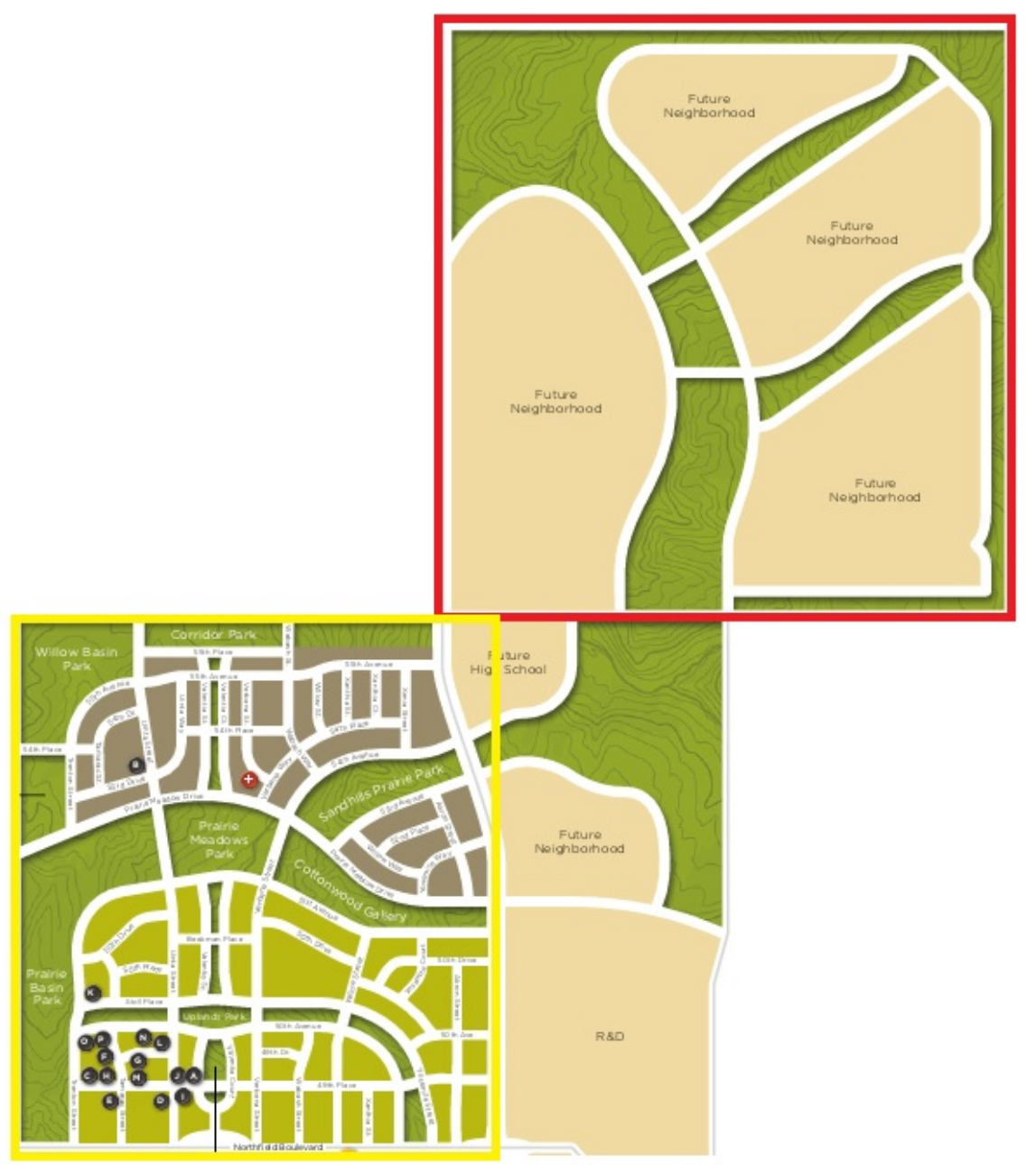

Figure 7. Stapleton future development map 


\section{Results}

With each scorecard checklist item earning a " 1 " or a " 0 " score based on the site walk and plan/specification review, the category results were combined to formulate a builder's overall ZERH compliance readiness score. The closer the overall score was to 1, the less work remained to bring the builder's baseline practices in line with ZERH requirements. Overall builder ZERH compliance readiness scores in Stapleton varied from 0.94 at the high end to 0.52 at the low end; most builders lacked in the water efficiency and indoor air quality checkpoints. Only one of the eight builders met the water efficiency checkpoint in its standard specification; a different builder was the only one to meet the lighting requirement checkpoint. Renewable ready was another checkpoint that showed low compliance in the builders' standard specifications. Figure 8 shows detailed results of the overall scores for all eight builders in Stapleton.

\begin{tabular}{|c|c|c|c|c|c|c|c|c|}
\hline 2014 Stapleton & 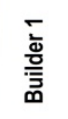 & 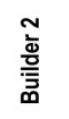 & $\begin{array}{l}\text { m } \\
\text { 总 } \\
\text { 志 }\end{array}$ & 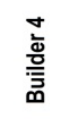 & 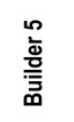 & 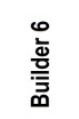 & 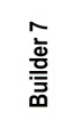 & 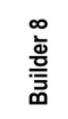 \\
\hline Overall Best Practice & 0.72 & 0.59 & 0.55 & 0.53 & 0.94 & 0.65 & 0.52 & 0.67 \\
\hline ENERGY STAR for Home Baseline & 1.00 & 1.00 & 1.00 & 1.00 & 1.00 & 1.00 & 0.50 & 1.00 \\
\hline ENERGY STAR Qualified Homes Version 3 & 1.00 & 1.00 & 1.00 & 1.00 & 1.00 & 1.00 & 0.50 & 1.00 \\
\hline Water Management System & 1.00 & 0.88 & 0.93 & 0.70 & 0.75 & 0.88 & 0.88 & 1.00 \\
\hline Water-Managed Site and Foundation & 1.00 & 1.00 & 0.71 & 1.00 & 1.00 & 1.00 & 1.00 & 1.00 \\
\hline Water-Managed Wall Assembly & 1.00 & 1.00 & 1.00 & 0.50 & 1.00 & 1.00 & 1.00 & 1.00 \\
\hline Water-Managed Roof Assembly & 1.00 & 0.50 & 1.00 & 0.50 & 0.00 & 0.50 & 0.50 & 1.00 \\
\hline Water-Managed Building Materials & 1.00 & 1.00 & 1.00 & 0.80 & 1.00 & 1.00 & 1.00 & 1.00 \\
\hline Envelope & 1.00 & 1.00 & 1.00 & 0.50 & 0.90 & 1.00 & 0.80 & 0.80 \\
\hline Fenestration & 1.00 & 1.00 & 1.00 & 0.00 & 0.50 & 1.00 & 1.00 & 0.00 \\
\hline Ceiling & 1.00 & 1.00 & 1.00 & 1.00 & 1.00 & 1.00 & 1.00 & 1.00 \\
\hline Wall Assembly & 1.00 & 1.00 & 1.00 & 0.00 & 1.00 & 1.00 & 1.00 & 1.00 \\
\hline Floor Assembly & $\mathrm{N} / \mathrm{A}$ & 1.00 & 1.00 & 1.00 & 1.00 & 1.00 & 1.00 & 1.00 \\
\hline Concrete Slab/Foundation Used & 1.00 & 1.00 & 1.00 & $\mathrm{~N} / \mathrm{A}$ & 1.00 & 1.00 & 0.00 & 1.00 \\
\hline Duct System & 1.00 & 1.00 & 0.60 & 0.75 & 1.00 & 0.80 & 0.50 & 1.00 \\
\hline Duct Location & 1.00 & 1.00 & 0.60 & 0.75 & 1.00 & 0.80 & 0.50 & 1.00 \\
\hline Water Efficiency & 0.00 & 0.00 & 0.00 & 0.00 & 1.00 & 0.00 & 0.00 & 0.00 \\
\hline $\begin{array}{r}\text { Hot Water Delivery System Shall Meet Efficient } \\
\text { Design Requirements }\end{array}$ & 0.00 & 0.00 & 0.00 & 0.00 & 1.00 & 0.00 & 0.00 & 0.00 \\
\hline Lighting and Appliances & 1.00 & 0.67 & 0.50 & 0.67 & 0.83 & 1.00 & 1.00 & 0.83 \\
\hline Appliances & $\mathrm{N} / \mathrm{A}$ & 1.00 & 0.50 & 0.50 & 1.00 & 1.00 & 1.00 & 1.00 \\
\hline Lighting & N/A & 0.00 & 0.00 & 0.50 & 0.50 & 1.00 & $\mathrm{~N} / \mathrm{A}$ & 0.50 \\
\hline Fans & 1.00 & 1.00 & 1.00 & 1.00 & 1.00 & $\mathrm{~N} / \mathrm{A}$ & 1.00 & 1.00 \\
\hline Indoor Air Quality & 0.00 & 0.00 & 0.00 & 0.00 & 1.00 & 0.00 & 0.00 & 0.00 \\
\hline EPA Indoor airPLUS & 0.00 & 0.00 & 0.00 & 0.00 & 1.00 & 0.00 & 0.00 & 0.00 \\
\hline Renewable Ready & 0.75 & 0.20 & 0.40 & 0.60 & 1.00 & 0.50 & 0.50 & 0.75 \\
\hline $\begin{array}{r}\text { Consolidated Renewable Energy Ready Home } \\
\text { (RERH) }\end{array}$ & 0.75 & 0.20 & 0.40 & 0.60 & 1.00 & 0.50 & 0.50 & 0.75 \\
\hline
\end{tabular}

Figure 8. ZERH Stapleton builder scorecard summary 


\section{Discussion}

Once the verifier walked the Stapleton site with the builder, the verifier was able to complete the ZERH scorecard created by IBACOS and to produce a scorecard and corresponding report that detailed the findings. Appendix $\mathrm{C}$ provides example scorecards for a Stapleton builder.

Each builder could use the scorecard and corresponding report to see where to focus its efforts to meet the ZERH standards by 2016, a timeline set forth by Forest City. Some builders expressed concern about increasing the cost of construction to meet the ZERH standard, especially where hot water distribution was concerned. Many of the floor plans do not allow for the quickresponse, low-waste hot water supply criteria without an occupant-controlled recirculation system.

Bringing ductwork inside conditioned space appeared to be another challenging area for builders as they worked with a floor plan in which space for chases and bulkheads may not be readily apparent. One strategy that is being explored is to simplify the duct layout and use properly selected registers to deliver air to the spaces to eliminate potential conflicts in meeting the ZERH standards. IBACOS continues to support the builders of Stapleton with the technical needs to meet areas of the ZERH standards where they are not yet compliant. 


\section{Conclusions}

IBACOS found that high-performance housing standards such as the ZERH program in a masterplanned community can be implemented. Once a developer decides to set a standard of ZERH, the developer then must invite selected builders to build in that community. The builders will decide if they want to build in a community with a mandated ZERH program and will need to understand the necessary steps to achieve the goals of the program by working with the highperformance verifier.

Communication between the builder and the verifier must be constant. The verifier will work through preliminary training with the builders in the community on a group level and on an individual level. This process will help the builder to design to ZERH standards either with a new floor plan or by reworking an existing floor plan. Once the floor plans are developed, the builder will work with the verifier to determine any gaps in meeting ZERH standards. The verifier also may walk the sites of homes under construction in a different area to check the compliance with ZERH, which will help the builder and tradespeople through visual examples. Ultimately, the developer will need to review and approve the builder's floor plans. Shortly afterward, the builder will begin marketing these ZERH homes.

Construction can begin once the builder's floor plans are approved. The builder and verifier again will work hand in hand to ensure construction to ZERH standards runs smoothly. This process includes the verifier walking the site, visually verifying any standards, and doing some short-term testing on the home.

All Stapleton builders received their scorecards and corresponding reports and know how their current products compare to ZERH standards. Most of the builders plan to design new floor plans for the ZERH area at Stapleton. The scorecards and reports should help them design with the ZERH standards in mind from the beginning and make the designs easier to implement throughout the construction process.

The compliance scorecards provide an excellent and simple way for builders to identify the areas of improvement that are needed to achieve the next tier in home performance. The results of the scorecard indicate many common areas among the builders with significant shortcomings in their practices relative to achieving ZERH compliance. Water efficiency, lighting, and indoor air quality all contained significant gaps. Only one builder was in alignment with EPA Indoor airPLUS. The availability of low-volatile organic compound cabinetry and other products was a concern to the builders. However, of greatest concern to the builders and representing the most significant challenge to implementation were the water efficiency measures. In general, the length of hot water distribution runs and the associated solutions - either between expensive recirculation systems or dramatic rework of the floor plans - will be the single largest challenge for builders to overcome.

At the time of this writing, the scorecards developed for this Stapleton project are not available for distribution or public use. For this project, the scorecards represent an example method to simplify - for a group of builders_- processes that are necessary to transition from building baseline homes to building ZERHs. Possible development of the scorecards for distribution is being reviewed. 


\section{References}

AEC. 2014. REM/Rate software, Version 14. Boulder, CO: Architectural Energy Corporation, accessed August 13, 2015: http://staging.archenergy.com/products/remrate.html.

Built Green 2014. Built Green Colorado program. Built Green, LLC, accessed August 13, 2015 : www.builtgreen.org.

City of Tucson. 2003. Guidelines for Developers and Builders. www.civano1.com/pages/documents/Civano_IMPACT_System_Dec_8_2003.pdf

Civano. 2002. Results from IBACOS Community-Scale Projects: Community of Civano.

Golden, CO: National Renewable Energy Laboratory (unpublished).

DOE. 2014. "DOE ZERH National Program Requirements (Revision 04)." Washington, D.C.: U.S. Department of Energy. http://energy.gov/sites/prod/files/2014/04/f15/ doe zero energy ready home requirements rev04.pdf.

DOE. n.d. "Guidelines for Participating in the DOE Zero Energy Ready Home." Washington, D.C.: U.S. Department of Energy, accessed August 13, 2015: http://energy.gov/eere/buildings/guidelines-participating-doe-zero-energy-ready-home.

ENERGY STAR. 2013. ENERGY STAR Qualified Homes Version 3, accessed August 13, 2015: www.energystar.gov/ia/partners/bldrs lenders raters/downloads/ National_Program_Requirements.pdf?073e-0f88.

EnergyGauge. 2013. EnergyGauge USA software, Version 3.1.00. Cocoa, FL: University of Central Florida, accessed August 8, 2015: www.energygauge.com/.

EPA. 2014a. U.S. Environmental Protection Agency Indoor airPLUS. Washington, D.C.: U.S. Environmental Protection Agency. www.epa.gov/indoorairplus/pdfs/construction_specifications.pdf.

EPA. 2014b. Renewable Energy Ready Homes. Washington, D.C.: U.S. Environmental Protection Agency, accessed August 13, 2015: www.energystar.gov/index.cfm?c=rerh.rerh_index.

Fraunhofer. 2015. WUFI. Munich, Germany: Fraunhofer, accessed August 13, 2015: https://wufi.de/en/.

ICC. 2006. International Energy Conservation Code 2006. Washington, D.C.: International Code Council.

ICC. 2009. International Energy Conservation Code 2009. Washington, D.C.: International Code Council.

ICC. 2012. International Energy Conservation Code 2012. Washington, D.C.: International Code Council, accessed August 13, 2015: http://publicecodes.cyberregs.com/icod/iecc/2012/. 
LBNL. 2014. “THERM.” Berkeley, CA: Lawrence Berkeley National Laboratory, accessed August 13, 2015: http://windows.lbl.gov/software/therm/therm.html.

Prahl, D. 2001. Community-Scale Building System Test and Evaluation Results. Letter Report. Pittsburgh, PA: IBACOS.

Prahl, D., and Newhouse, E. 2003. Conference or Journal Paper: "Results from CommunityScale Projects.” Golden, CO: National Renewable Energy Laboratory (unpublished). 


\section{Appendix A: Full Zero Energy Ready Home Scorecard for a Stapleton Builder}




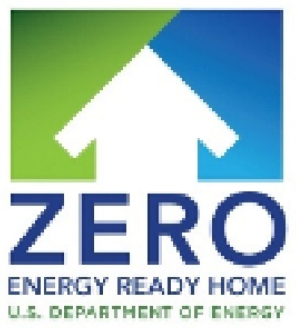

\section{Zero Energy Ready Home Audit}

Sample Stapleton Builder

Date Delivered: 2014-06-04 


\section{Best Practices Scorecard Summary: Zero Energy Ready Home}

\section{Sample Stapleton Builder}

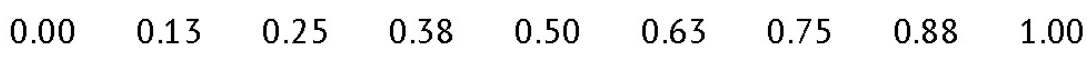

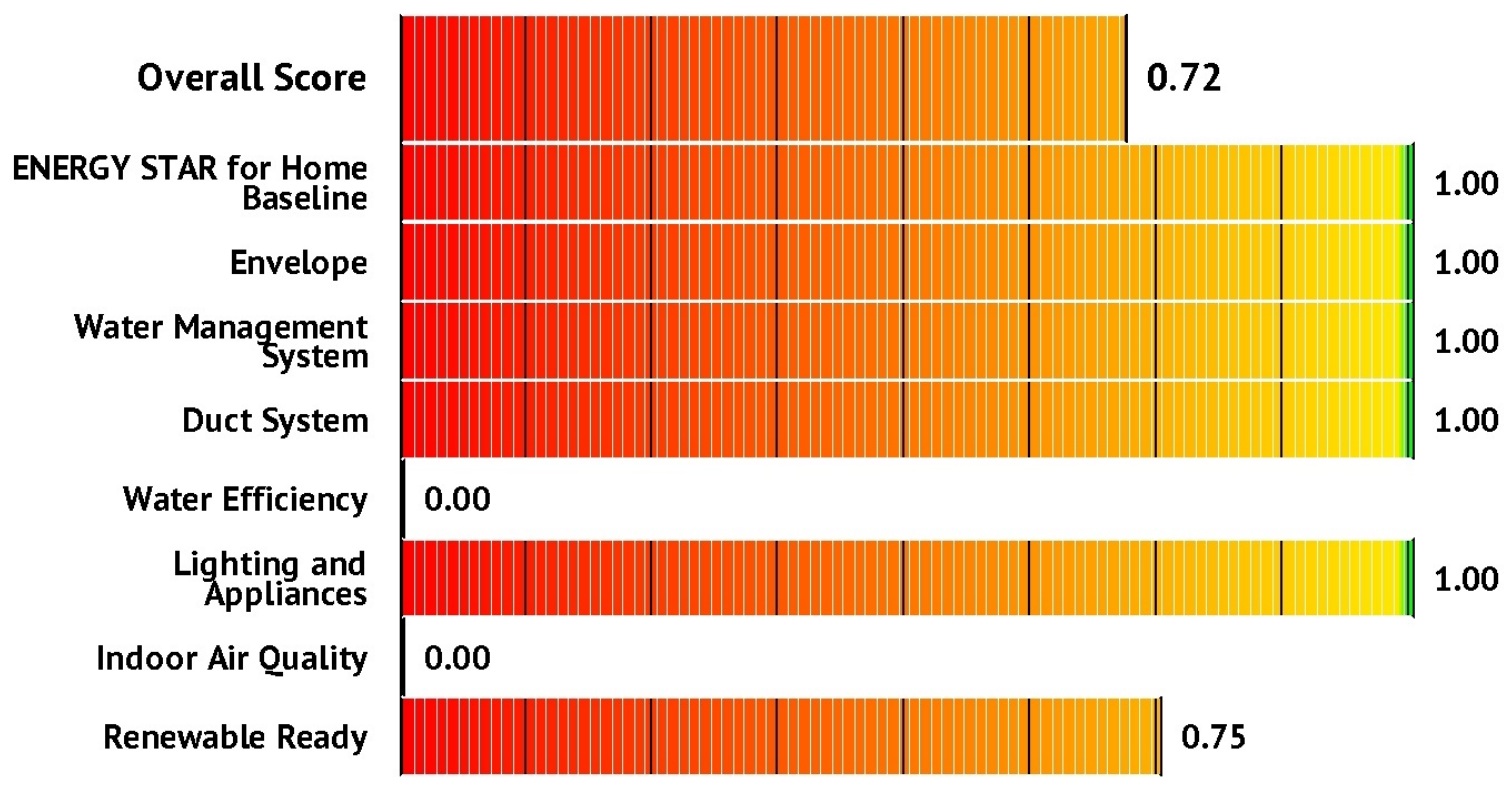

\section{Overview}

\section{Scorecard Overview}

IBACOS ${ }^{\circledR}$ uses a systematic process to assess the builders construction practices and compare them to the Zero Energy Ready Home Checklist, focusing on critical construction defect risk components.

During May, 2014, IBACOS conducted an extensive field walk of several communities within the Stapleton development that are currently under construction. We observed a wide range of product types in all stages of construction, collected data on their current construction practices, and identified their compliance with the Zero Energy Ready Home requirements.

IBACOS uses an automated scoring system that provides a more detailed, consistent, and uniform evaluation. Each sub-category within the building process is rated for the quality of the practices observed. IBACOS took an average score for each of the eight categories to generate the overall score. Total scores in the main performance categories are tallied and shown above.

\section{Copyright Notice}

The information contained within this report is the property of Builder and IBACOS, and may not be reproduced or used without written permission.

Copyright (C) 2014 IBACOS, Inc. 


\section{Best Practice Scorecard: Zero Energy Ready Home}

\subsection{2}

1.00

1.00

\section{Overall Zero Energy Ready Home Best Practice Score}

ENERGY STAR Qualified Homes Version 3

The following checklists shall be permitted to be completed for a batch of homes using a RESNET-approved sampling protocol. Sampling is not permitted for the HVAC System Quality Installation Contractor Checklist.

HVAC System Quality Installation Contractor Checklist: HVAC system checklist could not be observed at the site visit It appears as if supply side ventilation filtered at the furnace box was being used, but this could also be a dedicated ventilation supply for an exhaust ventilation strategy.

For supply ventilation, modeling the watt draw of the furnace should raise the HERS Index; this is not an issue for ESv3 but will be an issue for ZERH. Lennox furnaces were installed. Refer to the checklist for more details.

Thermal Enclosure System Rater Checklist: The houses observed in appear to fully comply with the Thermal Enclosure Checklist (See the TEC for more details.) For ZERH, compliance with the 2012 IECC insulation levels is required but this should not be difficult because the UA trade-off can be used to get there. No changes to the current practices should be required.

HVAC System Quality Installation Rater Checklist: Some flex duct is being used, but

1 some appears to be compressed and/or run with sharp bends. All duct observed was in conditioned space, which is a requirement for ZERH. Only ranch homes were observed. Refer to the checklist for more details.

\section{General Observations:}

appears to be using the performance path for ESv3. Tankless water heaters also are being used, which will help to meet the ZERH HERS Index requirements. 


\section{Fenestration}

Windows shall meet the ENERGY STAR Window Product Criteria which are in force at the time of project permitting. For homes achieving PHIUS+ certification where triple glazed window assemblies with thermal breaks/spacers between the panes are used, such windows are deemed to meet this requirement even in the absence of an ENERGY STAR certification.

One side-hinged opaque door assembly up to 24 square feet in area shall be exempt from the U-factor

requirements and shall be excluded from area-weighted averages calculated using a) and b), above;

Fenestration utilized as part of a passive solar design shall be exempt from the U-factor and SHGC requirements, and shall be excluded from area-weighted averages calculated using a) and b), above. Exempt windows shall be facing within 45 degrees of true South and directly coupled to thermal storage mass that has a heat capacity $>20 \mathrm{btu} / \mathrm{ft} 3 \mathrm{x} \circ \mathrm{F}$ and provided in a ratio of at least $3 \mathrm{sq}$. ft. per sq. ft. of South facing fenestration. Generally, thermal mass materials will be at least 2 in. thick.

\section{Window: U-Factor Requirement met:} below grade.

1

Requirement: An area-weighted average of fenestration products shall be permitted to satisfy the U-factor requirements.

Window: Proper Glazing technique: It appears that the large sliding glass doors also have good U-values. Some doors could have very high U-values, which could throw off the area weighted average.

Requirement: An area-weighted average of fenestration products $\geq 50 \%$ glazed shall be permitted to satisfy the SHGC requirements.

\section{Ceiling}

Insulation levels in a home shall meet or exceed the component insulation requirements in the 2012 International Energy Conservation Code (IECC).

Ceiling with Attic Space: At the site visit, R-38 values were observed. Raised heel trusses would allow at least an R-30 over the top plate. For ZERH, this becomes R-38 and $\mathrm{R}-49$, as already stated.

1

Requirement: For ceilings with attic spaces, $\mathrm{R}$-30 shall satisfy the requirement for $\mathrm{R}$ 38 , and R-38 shall satisfy the requirement for R-49 wherever the full height of uncompressed insulation at the lower R-value extends over the wall top plate at the eaves. See ZERH checklist for al ternative calculations. 
Insulation levels in a home shall meet or exceed the component insulation requirements in the 2012 International Energy Conservation Code (IECC).

\section{1}

Proper Wall Insulation Used: Although insulation installation could not be observed at the site visit, the supervisor said blown fiberglass insulation was being used. The air sealing package looked good. Fire blocking/insulation in the basement was interesting; refer to pic tures of batts and foam.

\section{N/A Floor Assembly}

Insulation levels in a home shall meet or exceed the component insulation requirements in the 2012 International Energy Conservation Code (IECC).

General Observations: Cantilevers or floors over garages were not observed in the houses visited.

\section{Concrete Slab/Foundation Used}

Insulation levels in a home shall meet or exceed the component insulation requirements in the 2012 International Energy Conservation Code (IECC).

Proper Slab/Foundation Used: 2012 IECC would require an increase to R-19 on

1 finished or R-15 on unfinished. However, it appears this can be traded off, so it should be acceptable to remain with R-11 blanket and R-13 batt in finished walls. 
Capillary breaks under slabs: It is unlikely this is being done.

Exterior surface of below grade foundations: This could not be observed, but it appears that foundations were being sprayed with damp-proofing coating.

Requirement: Exterior surface of below-grade walls of basements $\&$ unvented crawlspaces finished as follows:

a) For poured concrete, masonry, \& insulated concrete forms, finish with dampproofing coating.

b) For wood framed walls, finish with polyethylene and adhesive or other equivalent waterproofing.

Vapor retarder: It appeared that blown fiberglass and a Class III vapor barrier were being used.

Sump pump covers: This could not be observed at the site visit

Requirement: Sump pump covers mechanically attached with full gasket seal or equivalent

Exterior drain tile: This could not be observed at the site visit

Requirement: Drain tile installed at the exterior side of footings of basement and crawlspace walls, with the top of the drain tile pipe below the bottom of the concrete slab or crawlspace floor. Drain tile surrounded with $\geq 6$ in. of $1 / 2$ to $3 / 4$ in. washed or clean gravel and with gravel layer fully wrapped with fabric cloth. Drain tile level or sloped to discharge to outside grade (daylight) or to a sump pump.

Slab sloping for drainage away from home: These appeared to be sloped correctly in the homes visited. However, metal flashing to the house was not lapped under the housewrap.

Requirement: Patio slabs, porch slabs, walks, and driveways sloped $\geq 0.25$ in. per ft away from the home to the edge of the surface or $10 \mathrm{ft}$, whichever is less.

Back-fill: The house observed was not complete but looked good.

Requirement: Backfill has been tamped, and the final grade sloped $\geq 0.5$ in. per $\mathrm{ft}$ away from home for $\geq 10 \mathrm{ft}$ 
Flashing for Masonry and Stucco Walls: This could not be observed at the site visit

Requirement: Flashing at bottom of exterior walls with weep holes included for masonry veneer and weep screed for stucco cladding systems, or equivalent drainage system.

Drainage Plane and Penetrations sealing: Some pan flashing issues were observed, and it appeared that a polyolefin housewrap was being used. Signs of damage from installation were observed. The Quickflash ${ }^{\circledR}$ looked good.

Requirement: Fully sealed continuous drainage plane behind exterior cladding that laps over flashing and fully sealed at all penetrations. Additional bond-break drainage plane layer provided behind all stucco and non-structural masonry cladding wall assemblies.

Flashing at openings: Overall, the Quickflash ${ }^{\circledR}$ looked good. One sequencing issue

1 was observed.

Requirement: Window and door openings were fully flashed.

Self Sealing bi tuminous membrane: This could not be confirmed at the site visit

Requirement: Self-sealing bituminous membrane or equivalent at all valleys \& roof deck penetrations

Flashing at Roof Intersections: During the site walk it was observed that the kick-out flashing was too small.

Requirement: Step and kick-out flashing at all roof-wall intersections, extending $\geq 4$ " on wall surface above roof deck and integrated shingle-style with drainage plane above; boot/collar flashing at all roof penetrations.

Gutter and Downspout Installation: Downspouts were routed away.

Requirement: For homes that don't have a slab-on-grade foundation and do have

1 expansive or collapsible soils, gutters \& amp; downspouts provided that empty to lateral piping that discharges water on sloping final grade $\geq 5 \mathrm{ft}$ from foundation or to underground catchment system not connected to the foundation drain system that discharges water $\geq 10 \mathrm{ft}$ from foundation. 
Carpeting Installation: A finished house was not observed.

Requirement: Wall-to-wall carpet not installed within $2.5 \mathrm{ft}$ of toilets, tubs, and showers.

Moisture-resistant backing material: This was not observed.

Requirement: Cement board or equivalent moisture-resistant backing material installed on all walls behind tub and shower enclosures composed of tile or panel assemblies with caulked joints. Paper-faced backerboard shall not be used.

1

Quality of Building Materials used: Building materials with visible signs of water damage or mold not installed or allowed to remain.

1 Moisture content of Framing members and Insulation products: Framing members \& insulation products having high moisture content not enclosed (e.g., with drywall) 


\subsection{0 \\ Duct System}

1.00

Duct Location

1

Ducts located in thermal and air barrier boundary: Only ranch-style home could be inspected at this site visit All ducts were inside conditioned space.

Exception 4: Transfer grilles that did not penetrate the attic were being used.

1

Requirement: Jump ducts that do not directly deliver conditioned air from the HVAC unit may be located in attics if all joints, including boot to drywall, are fully air sealed with mastic or foam, and the jump duct is fully buried under the attic insulation.

Exception 6: Basements were insulated and conditioned.

1 Requirement: Ducts were located in a basement, which is with in the home's thermal boundary. 


\section{$0.00 \quad$ Water Efficiency}

Hot Water Delivery System: Home-run maniblock systems were being installed.

$0 \quad$ Requirement: To minimize water wasted while waiting for hot water, the hot water distribution system shall store no more that 0.5 gallons of water in any piping/manifold between the hot water source and any hot water fixture

Occupant-controlled or Occupancy sensor-based recirculation systems: Occupantcontrolled or Occupancy sensor-based recirculation systems not used

0 Requirement: The 0.5 galllon storage limit shall be measured from the point where the branch feeding the fixture branches off the recirculation loop, to the fixture itself. To verify that the system stores nor more than 0.5 gallons, verifiers shall calculate the stored volume uding the pinping or tubing inside diameter and the length of the piping/tubing 


\section{$1.00 \quad$ Lighting and Appliances}

N/A Appliances

General Observations: Appliances were not observed; however, ZERH requires all appliances to be ES. In this market, dishwashers are standard, but the rest are option. All options must be ES.

N/A Lighting

ONE of the following is required. Submit $n /$ a for the other

General Observations: The option used would be ES lamps (bulbs) installed in a minimum of $80 \%$ of sockets. This would also swing the HERS Index for ZERH; therefore, $100 \%$ use is recommended.

1.00

Fans

1

All installed bathroom ventilation uni ts are ENERGY STAR qualified: All appeared to be ES. 
0.00

Indoor Air Quality

0.00

EPA Indoor airPLUS

0

The home is Certified under EPA Indoor airPLUS: Some significant things will need to be done to meet the IAP. Radon was good. Material section will be a challenge. 


\section{Consolidated RERH}

Condition 1: N/A at this location

Condition 1 Requirement: If solar photovoltaic or solar hot water system is already included with the home, then compliance with the photovoltaic or solar hot water RERH checklist, is not required.

Renewable Energy Ready Home (RERH) consolidated checklist: There was no sign of chases or other RERH thinking. In Colorado, there should be a conduit running or

0 something similar, per state law. What appeared to be running was only for low voltage.

This checklist only applies under all of the conditions:

Condition 2: Condition 2 Requirement: Location, based on zip code, has at least 5 $\mathrm{kW} / \mathrm{m} 2 /$ day average daily solar radiation based on annual solar insolation using this online tool: http://pvwatts.nrel.gov/

1 Condition 3: Condition 3 Requirement: Location does not have significant natural shading (e.g., trees, tall buildings on the south-facing roof)

Condition 4: All would have roof area. Orientation is an issue; lots are random \& not laid out with solar access in mind

1 Condition 4 Requirement: Home as designed has adequate free roof area within +/$45 \circ$ of true south as noted in the table below. Note that in some cases a house may have insufficient roof area for the Solar Electric RERH checklist, but it may still have the minimum roof area for the Solar Thermal RERH checklist, and would therefore have to comply with the Solar Thermal RERH checklist 


\section{Appendix B: U.S. Department of Energy Zero Energy Ready Home National Program Requirements}




\section{DOE Zero Energy Ready Home National Program Requirements (Rev. 04)}

\section{ZERO April 21, 2014}

To qualify as a DOE Zero Energy Ready Home, a home shall meet the minimum requirements specified below, be verified and field-tested in accordance with HERS Standards by an approved verifier, and meet all applicable codes ${ }^{1}$. Builders may meet the requirements of either the Performance Path or the Prescriptive path to qualify a home. ${ }^{2}$ Buildings eligible for qualification are: single family detached and attached dwelling units; dwelling units in multifamily buildings with 3 stories or fewer above-grade ${ }^{3,4}$; dwelling units in multifamily buildings with 4 or 5 stories above-grade ${ }^{3,4}$ that have their own heating, cooling, and hot water systems ${ }^{5}$ separate from other units and where dwelling units occupy $80 \%$ or more of the occupiable square footage of the building. When evaluating mixed-use buildings for eligibility, exclude commercial / retail space when assessing whether the $80 \%$ threshold has been met.

Homes may qualify for DOE Zero Energy Ready Home using either the Prescriptive Path or Performance Path in all locations except CA and WA, for which regional program requirements have been developed. Note that compliance with these guidelines is not intended to imply compliance with all local code requirements that may be applicable to the home to be built.

\section{DOE Zero Energy Ready Home Prescriptive Path}

The prescriptive path provides a single set of measures that can be used to construct a DOE Zero Energy Ready Home labeled home. Modeling is not required, but no tradeoffs are allowed. Follow these steps to use the prescriptive path:

1. Assess eligibility by using the number of bedrooms in the home to be built to determine the conditioned floor area (CFA) of the Benchmark Home, Exhibit 3. If the CFA of the home to be built exceeds this value, the performance path shall be used.

2. If the prescriptive path is eligible for use based on the prior step, build the home using the mandatory requirements for all labeled homes, Exhibit 1, and all requirements of the DOE Zero Energy Ready Home Target Home, Exhibit 2. The rigor of the specifications in Exhibit 2 shall be met or exceeded.

3. Verify that all requirements have been met using an approved verifier. ${ }^{6}$

All homes certified through the Prescriptive Path shall be submitted to DOE (email: doechallengehome@newportpartnersllc.com).

\section{DOE Zero Energy Ready Home Performance Path}

While all mandatory requirements for labeled homes in Exhibit 1 shall be met, the performance path provides flexibility to select a custom combination of measures that meet the performance level of the DOE Zero Energy Ready Home HERS Target Home (Exhibit 2). Modeling is required, but measures can be optimized for each particular home or builder. Follow the steps below to use the performance path with RESNET-accredited Home Energy Rating Software programs:

1. The HERS Index of the DOE Zero Energy Ready Home Target Home is determined. The DOE Zero Energy Ready Home Target Home is identical to the home that will be built, except that it is configured with the energy efficiency features of the DOE Zero Energy Ready Home Target Home as defined in Exhibits 1 and 2. Note, any state energy code requirements that exceed those specified on Exhibit 2 take precedence for purposes of determining the DOE Zero Energy Ready Home Target Home ${ }^{7}$. The HERS Index of the Target Home is automatically calculated in accordance with the RESNET Mortgage Industry National Home Energy Rating Standards.

2. A size modification factor is next calculated using the following equation:

$$
\text { Size Modification Factor }=\left[C F A_{\text {Benchmark Home }} / \text { CFA }_{\text {Home To Be Built }}{ }^{0.25} \text {, but not to exceed } 1.0\right.
$$

Where:

CFA Benchmark Home $=$ Conditioned Floor Area of the Benchmark Home, using Exhibit 3

CFA Home to be Built = Conditioned Floor Area of the Home to be Built

Since the Size Modification Factor cannot exceed 1.0, it only modifies the HERS Index score for homes larger than the CFA of the Benchmark Home.

3. The HERS Index of the DOE Zero Energy Ready Home Target Home is calculated next ${ }^{8}$ :

Effective for Homes

Permitted Starting 6/21/2014
Revised April 21, 2014

Page 1 of 9 


\section{DOE Zero Energy Ready Home HERS Index Target = HERS Index of DOE Zero Energy Ready Home Target Home x Size Modification Factor}

4. Complete HERS software calculations for preferred set of energy measures and verify resulting HERS Index Score at or below DOE Zero Energy Ready Home Target Home HERS Index Score modified, as required, for house size.

5. Construct the home using measures that result in a HERS Index at or below the DOE Zero Energy Ready Home HERS Target, calculated above, and the mandatory requirements for all labeled homes, Exhibit 1.

6. Verify that all requirements have been met using an approved verifier.

All homes certified through the Performance Path shall be submitted to DOE by submitting the compliance verification report to doechallengehome@newportpartnersllc.com.

\section{Exhibit 1: DOE Zero Energy Ready Home Mandatory Requirements for All Labeled Homes}

\begin{tabular}{|c|c|c|}
\hline Area of Improvement & & Mandatory Requirements \\
\hline $\begin{array}{l}\text { 1. ENERGY STAR for } \\
\text { Homes Baseline }\end{array}$ & & Certified under ENERGY STAR Qualified Homes Version $3^{9,10}$ \\
\hline 2. Envelope ${ }^{11}$ & $\begin{array}{l}\square \\
\square\end{array}$ & $\begin{array}{l}\text { Fenestration shall meet or exceed latest ENERGY STAR requirements }{ }^{12,13} \\
\text { Ceiling, wall, floor, and slab insulation shall meet or exceed } 2012 \text { IECC levels }{ }^{14,15}\end{array}$ \\
\hline 3. Duct System & $\square$ & Ducts located within the home's thermal and air barrier boundary ${ }^{16}$ \\
\hline 4. Water Efficiency & $\square$ & Hot water delivery systems shall meet efficient design requirements ${ }^{17}$ \\
\hline $\begin{array}{l}\text { 5. Lighting \& } \\
\text { Appliances }^{18}\end{array}$ & & $\begin{array}{l}\text { All installed refrigerators, dishwashers, and clothes washers are ENERGY STAR qualified. } \\
80 \% \text { of lighting fixtures are ENERGY STAR qualified or ENERGY STAR lamps (bulbs) in } \\
\text { minimum } 80 \% \text { of sockets } \\
\text { All installed bathroom ventilation and ceiling fans are ENERGY STAR qualified }\end{array}$ \\
\hline 6. Indoor Air Quality & $\square$ & Certified under EPA Indoor airPLUS ${ }^{10}$ \\
\hline 7. Renewable Ready ${ }^{19}$ & & Consolidated Renewable Energy Ready Home (RERH) Checklist \\
\hline
\end{tabular}

Exhibit 2: DOE Zero Energy Ready Home Target Home ${ }^{7,20}$

\begin{tabular}{|c|c|c|c|}
\hline \multicolumn{4}{|l|}{ HVAC Equipment $^{21}$} \\
\hline & $\begin{array}{c}\text { Hot Climates } \\
(2012 \text { IECC Zones } 1,2)^{22}\end{array}$ & $\begin{array}{c}\text { Mixed Climates } \\
\text { (2012 IECC Zones 3, } \\
4 \text { except Marine) }\end{array}$ & $\begin{array}{c}\text { Cold Climates } \\
(2012 \text { IECC Zones } \\
4 \text { Marine } 5,6,7,8)\end{array}$ \\
\hline AFUE & $80 \%$ & $90 \%$ & $94 \%$ \\
\hline SEER & 18 & 15 & 13 \\
\hline HSPF & 8.2 & 9 & $10^{23}$ \\
\hline Geothermal Heat Pump & \multicolumn{3}{|c|}{ ENERGY STAR EER and COP Criteria } \\
\hline $\begin{array}{l}\text { ASHRAE 62.2 Whole-House } \\
\text { Mechanical Ventilation System }\end{array}$ & $\begin{array}{c}1.4 \mathrm{cfm} / \mathrm{W} ; \\
\text { no heat exchange }\end{array}$ & $\begin{array}{c}1.4 \mathrm{cfm} / \mathrm{W} \\
\text { no heat exchange }\end{array}$ & $\begin{array}{c}1.2 \mathrm{cfm} / \mathrm{W} \\
\text { heat exchange with } 60 \% \text { SRE }\end{array}$ \\
\hline \multicolumn{4}{|l|}{ Insulation and Infiltration } \\
\hline \multicolumn{4}{|c|}{$\begin{array}{l}\text { - Insulation levels shall meet the } 2012 \text { IECC and achieve Grade } 1 \text { installation, per RESNET standards. } \\
\text { - Infiltration }{ }^{24}(\mathrm{ACH} 5): \quad 3 \text { in CZ's } 1-2 \quad \mid 2.5 \text { in CZ's } 3-4 \mid \quad 2 \text { in CZ's 5-7 | } 1.5 \text { in CZ } 8\end{array}$} \\
\hline
\end{tabular}




\section{DOE Zero Energy Ready Home National Program Requirements (Rev. 04)}

ZERO April 21, 2014

\begin{tabular}{|l|c|c|c|}
\hline & $\begin{array}{c}\text { Wot Climates } \\
(2012 \text { IECC Zones 1,2, })\end{array}$ & $\begin{array}{c}\text { Mixed Climates } \\
(2012 \text { IECC Zones 3, } \\
4 \text { except Marine })\end{array}$ & $\begin{array}{c}\text { Cold Climates } \\
(2012 \text { IECC Zones } \\
4 \text { Marine 5,6,7,8) }\end{array}$ \\
\hline SHGC & 0.25 & 0.27 & any \\
\hline U-Value & 0.4 & 0.3 & 0.27 \\
\hline $\begin{array}{l}\text { Homes qualifying through the Prescriptive Path with a total window-to-floor area greater than 15\% shall have adjusted } \\
\text { U-values or SHGCs. }{ }^{28}\end{array}$ \\
\hline Water Heater \\
\hline ENERGY STAR minimum; for heating oil water heaters use EF = 0.60 \\
\hline Thermostat ${ }^{29}$ \\
\hline - Programmable thermostat (except for zones with radiant heat) \\
\hline Lighting \& Appliances \\
- For purposes of calculating the DOE Zero Energy Ready Home Target Home HERS Index, homes shall be modeled with an \\
ENERGY STAR dishwasher, ENERGY STAR refrigerator, ENERGY STAR ceiling fans, and ENERGY STAR lamps (bulbs) in \\
80\% of sockets or 80\% of lighting fixtures are ENERGY STAR Qualified. \\
\hline
\end{tabular}

Exhibit 3: Benchmark Home Size ${ }^{30}$

\begin{tabular}{|l|c|c|c|c|c|c|c|c|}
\hline Bedrooms in Home to be Built & 0 & 1 & 2 & 3 & 4 & 5 & 6 & 7 \\
\hline Conditioned Floor Area Benchmark Home & 1,000 & 1,000 & 1,600 & 2,200 & 2,800 & 3,400 & 4,000 & 4,600 \\
\hline
\end{tabular}

\section{Footnotes:}

\footnotetext{
${ }^{1}$ Where requirements of the local codes, covenants, manufacturers' installation instructions, or engineering documents overlap with the requirements of these guidelines, DOE offers the following guidance:

a. In cases where the overlapping requirements exceed the DOE Zero Energy Ready Home guidelines, these overlapping requirements shall be met;

b. In cases where overlapping requirements conflict with a requirement of these DOE Zero Energy Ready Home guidelines, then the home is exempt from conflicting requirement within these guidelines. However, certification shall only be allowed if the Rater has determined that no equivalent option is available that could meet the intent of the conflicting requirement of these DOE Zero Energy Ready Home guidelines. Note that, under the Performance Path, a home must still meet the Target Home HERS Index Target. Therefore, other efficiency measures may be needed to compensate for the omission of the conflicting requirement.
}

2 In the event that a Rater is not able to determine whether an item is consistent with the intent of a provision, (e.g., an alternative method of meeting a checklist requirement has been proposed), then the Rater shall consult their Provider. If the Provider also cannot make this determination, then the Rater or Provider shall report the issue to DOE prior to project completion at: doechallengehome@newportpartnersllc.com and will typically receive an initial response within 5 business days. If DOE believes the current program guidelines are sufficiently clear to determine whether the intent has been met, then this guidance will be provided to the Partner and enforced beginning with the house in question. However, if DOE believes the program guidelines require revisions to make the intent clear, then this guidance will be provided to the Partner but only enforced for homes permitted after a specified transition period after the release of the revised guidelines, typically 60 days in length. This process will allow DOE to make formal policy decisions as Partner questions arise and to disseminate these policy decisions through the periodic release of revised program documents to ensure consistent application of the program guidelines. 
${ }^{3}$ A dwelling unit, as defined by the 2012 IECC, is a single unit that provides complete independent living facilities for one or more persons, including permanent provisions for living, sleeping, eating, cooking, and sanitation.

${ }^{4}$ Any above-grade story with $20 \%$ or more occupiable space, including commercial space, shall be counted towards the total number of stories for the purpose of determining eligibility to participate in the program. The definition of an 'abovegrade story' is one for which more than half of the gross surface area of the exterior walls is above-grade. All below-grade stories, regardless of type, shall not be included when evaluating eligibility. Per ASHRAE 62.2-2010, occupiable space is any enclosed space inside the pressure boundary and intended for human activities or continual human occupancy, including, but not limited to, areas used for living, sleeping, dining, and cooking, toilets, closets, halls, storage and utility areas, and laundry areas.

${ }^{5}$ Central systems for domestic hot water are allowed if solar energy provides at least $50 \%$ of the domestic hot water needs for the residential units.

${ }^{6}$ The term "verifier" refers to the person completing the third-party inspections required for qualification. This party may be a certified Home Energy Rater, Rating Field Inspector, BOP Inspector, or an equivalent designation as determined by a Verification Oversight Organization such as RESNET.

${ }^{7}$ State energy code specifications that exceed the DOE Zero Energy Ready Home National Program Requirements always take precedence and shall be used instead of DOE Zero Energy Ready Home specifications to determine DOE Zero Energy Ready Home compliance.

${ }^{8}$ On-site power generation may not be used to qualify a home for the DOE Zero Energy Ready Home Target Home requirements, but can be used to achieve additional HERS Index Score reductions needed for homes larger than the Benchmark Home.

${ }^{9}$ Consistent with the ENERGY STAR for Homes V3 allowance for sampling, the Thermal Enclosure System Rater Checklist and the HVAC System Quality Installation Rater Checklist shall be permitted to be completed for a batch of homes using a RESNET-approved sampling protocol. The Indoor airPLUS Verification Checklist may also be completed using a RESNET-approved sampling protocol. Sampling shall not be permitted to complete the HVAC System Quality Installation Contractor Checklist.

With respect to Provision 2.2 within the ENERGY STAR Qualified Homes, Version 3 (REV06) Thermal Enclosure System Rater Checklist: where ceiling, wall, or floor assembly insulation is installed "blind" between layers of sheathing and therefore cannot be visually inspected, such assemblies are deemed equivalent to a RESNET-defined Grade 1 installation if the assembly insulation level is at least $50 \%$ greater than the specified value for the DOE Zero Energy Ready Home Target Home, based on nominal R-value.

${ }^{10}$ For homes achieving PHIUS+ certification, DOE will allow compliance with the 2012 IRC kitchen ventilation airflow rates (M 1507.4) as an alternative to those specified within ASHRAE 62.2. This alternative will remain in effect while DOE works to develop an ASHRAE 62.2-compliant solution optimized for very low-load homes.

${ }^{11}$ Building envelope assemblies, including exterior walls and unvented attic assemblies (where used), shall comply with the relevant vapor retarder provisions of the 2012 International Residential Code (IRC). If the project is instead meeting 2015 IECC insulation levels (see footnote 15 below), then assemblies shall comply with the relevant vapor retarder provisions of the 2015 IRC.

${ }^{12}$ Windows shall meet the ENERGY STAR Window Product Criteria which are in force at the time of project permitting. See www.energystar.gov/windows for current ENERGY STAR Window Product Criteria. For homes achieving PHIUS+

Effective for Homes

Revised April 21, 2014

Page 4 of 9

Permitted Starting 6/21/2014 
certification where triple glazed window assemblies with thermal breaks/spacers between the panes are used, such windows are deemed to meet this requirement even in the absence of an ENERGY STAR certification.

${ }^{13}$ Fenestration shall meet the applicable ENERGY STAR Window Product Criteria for $U$ and SHGC, with the following exceptions:

a. An area-weighted average of fenestration products shall be permitted to satisfy the U-factor requirements;

b. An area-weighted average of fenestration products $\geq 50 \%$ glazed shall be permitted to satisfy the SHGC requirements;

c. 15 square feet of glazed fenestration per dwelling unit shall be exempt from the U-factor and SHGC requirements, and shall be excluded from area-weighted averages calculated using a) and b), above;

d. One side-hinged opaque door assembly up to 24 square feet in area shall be exempt from the U-factor requirements and shall be excluded from area-weighted averages calculated using a) and b), above;

e. Fenestration utilized as part of a passive solar design shall be exempt from the U-factor and SHGC requirements, and shall be excluded from area-weighted averages calculated using a) and b), above. Exempt windows shall be facing within 45 degrees of true South and directly coupled to thermal storage mass that has a heat capacity $>20$ $\mathrm{btu} / \mathrm{ft}^{3} \mathrm{x}^{\circ} \mathrm{F}$ and provided in a ratio of at least $3 \mathrm{sq}$. ft. per sq. ft. of South facing fenestration. Generally, thermal mass materials will be at least 2 in. thick.

${ }^{14}$ Insulation levels in a home shall meet or exceed the component insulation requirements in the 2012 International Energy Conservation Code (IECC) - Table R402.1.1. The following exceptions apply:

a. Steel-frame ceilings, walls, and floors shall meet the insulation requirements of the 2012 IECC - Table 402.2.6.

b. For ceilings with attic spaces, R-30 shall satisfy the requirement for R-38 and R-38 shall satisfy the requirement for R-49 wherever the full height of uncompressed insulation at the lower R-value extends over the wall top plate at the eaves. This exemption shall not apply if the alternative calculations in d) are used;

c. For ceilings without attic spaces, R-30 shall satisfy the requirement for any required value above R-30 if the design of the roof / ceiling assembly does not provide sufficient space for the required insulation value. This exemption shall be limited to $500 \mathrm{sq}$. ft. or $20 \%$ of the total insulated ceiling area, whichever is less. This exemption shall not apply if the alternative calculations in d) are used;

d. An alternative equivalent $U$-factor or total UA calculation may also be used to demonstrate compliance, as follows: An assembly with a U-factor equal or less than specified in 2012 IECC Table 402.1 .3 complies. A total building thermal envelope UA that is less than or equal to the total UA resulting from the U-factors in Table 402.1.3 also complies. The insulation levels of fenestration, ceilings, walls, floors, and slabs can be traded off using the UA approach under both the Prescriptive and the Performance Path. Also, note that while ceiling and slab insulation can be included in trade-off calculations, Items 4.1 through 4.3 of the ENERGY STAR for Homes V3 Thermal Enclosure System Rater Checklist shall be met regardless of the UA tradeoffs calculated. The UA calculation shall be done using a method consistent with the ASHRAE Handbook of Fundamentals and shall include the thermal bridging effects of framing materials. The calculation for a steel-frame envelope assembly shall use the ASHRAE zone method or a method providing equivalent results, and not a series-parallel path calculation method.

15

In states where the residential provisions of the 2012 International Energy Conservation Code (IECC) have been adopted, qualifying homes must instead meet the envelope insulation requirements of the 2015 IECC, effective at 6 months after the 2015 IECC publication date. DOE will maintain a list of state-specific compliance requirements and timelines on the DOE Zero Energy Ready Home website.

${ }^{16}$ Exceptions and alternative compliance paths to locating $100 \%$ of forced-air ducts in home's thermal and air barrier boundary are:

a. Up to 10' of total duct length is permitted to be outside of the home's thermal and air barrier boundary.

b. Ducts are located in an unvented attic, regardless of whether this space is conditioned with a supply register

Effective for Homes

Revised April 21, 2014

Page 5 of 9

Permitted Starting 6/21/2014 
c. Ducts are located in a vented attic with all of the following characteristics:

i. In Moist climates (Zones 1A, 2A, 3A, 4A, 5A, 6A and 7A per 2012 IECC Figure R301.1) and Marine climates (all "C" Zones per 2012 IECC Figure R301.1), minimum R-8 duct insulation with an additional minimum 1.5" of closed-cell spray foam insulation encapsulating the ducts; total duct leakage $\leq 3$ CFM25 per $100 \mathrm{ft}^{2}$ of conditioned floor area; and ductwork buried under at least 2" of blown-in insulation.

ii. In Dry climates (all "B" Zones per 2012 IECC Figure R301.1), minimum R-8 duct insulation; total duct leakage $\leq 3$ CFM25 per $100 \mathrm{ft}^{2}$ of conditioned floor area; and ductwork buried under at least 3.5 " of blown-in insulation.

Note that in either of these designs the HVAC equipment must still be located within the home's thermal and air barrier boundary.

d. Jump ducts which do not directly deliver conditioned air from the HVAC unit may be located in attics if all joints, including boot-to-drywall, are fully air sealed with mastic or foam, and the jump duct is fully buried under the attic insulation.

e. Ducts are located within an unvented crawl space

f. Ducts are located in a basement which is within the home's thermal boundary

g. Ductless HVAC system is used

${ }^{17}$ Hot water delivery systems shall meet efficiency requirements found in Section 3.3 of the EPA WaterSense SingleFamily New Home Specification. Under the DOE Zero Energy Ready Home program, the approved verifier may also confirm compliance with these requirements. These requirements are stated below:

Hot Water Delivery System - To minimize water wasted while waiting for hot water, the hot water distribution system shall store no more than 0.5 gallons ( 1.9 liters) of water in any piping/manifold between the hot water source and any hot water fixture. In the case of occupant-controlled or occupancy sensor-based recirculation systems, the 0.5 gallon (1.9 liter) storage limit shall be measured from the point where the branch feeding the fixture branches off the recirculation loop, to the fixture itself. To verify that the system stores no more than 0.5 gallons (1.9 liters), verifiers shall calculate the stored volume using the piping or tubing inside diameter and the length of the piping/tubing.

To account for the additional water that must be removed from the system before hot water can be delivered, no more than 0.6 gallons ( 2.3 liters) of water shall be collected from the hot water fixture before hot water is delivered. Recirculation systems must be based on an occupant-controlled switch or an occupancy sensor. Recirculation systems that are activated based solely on a timer and/or temperature sensor do not meet this requirement. Recirculation systems which operate based on "adaptive" scheduling, meaning that they "learn" the hot water demand profile in the home and adapt their operation to meet this profile, are permitted at this time. To verify that the system meets the 0.6 gallon ( 2.3 liter) limit, verifiers shall first initiate operation of occupantcontrolled or occupancy sensor-based recirculation systems, if present, and let such systems run for at least 40 seconds. Next, a bucket or flow measuring bag (pre-marked for 0.6 gallons) shall be placed under the hot water fixture. The hot water shall be turned on completely, a digital thermometer placed in the stream of water just where it meets the water being collected, and the starting temperature recorded. Once the water reaches the premarked line (approximately 24 seconds for a lavatory faucet), the water shall be turned off and the ending temperature reading at the same location recorded. The temperature must increase by $10^{\circ} \mathrm{F}$. Only the fixture with the greatest stored volume between the fixture and the hot water source (or recirculation loop) needs to be tested.

${ }^{18}$ Further efficiency and savings can be achieved by installing ENERGY STAR qualified products in addition to those required.

19 The Renewable Energy Ready Home (RERH) consolidated checklist only applies under all of the following conditions: 
a. If a solar photovoltaic or solar hot water system is already included with the home, then compliance with the solar photovoltaic or solar hot water RERH checklist, respectively, is not required.

b. Location, based on zip code, has at least $5 \mathrm{kWh} / \mathrm{m}^{2} /$ day average daily solar radiation based on annual solar insolation using this online tool: http://pvwatts.nrel.gov/

\section{Average Daily Solar Radiation Per Month}

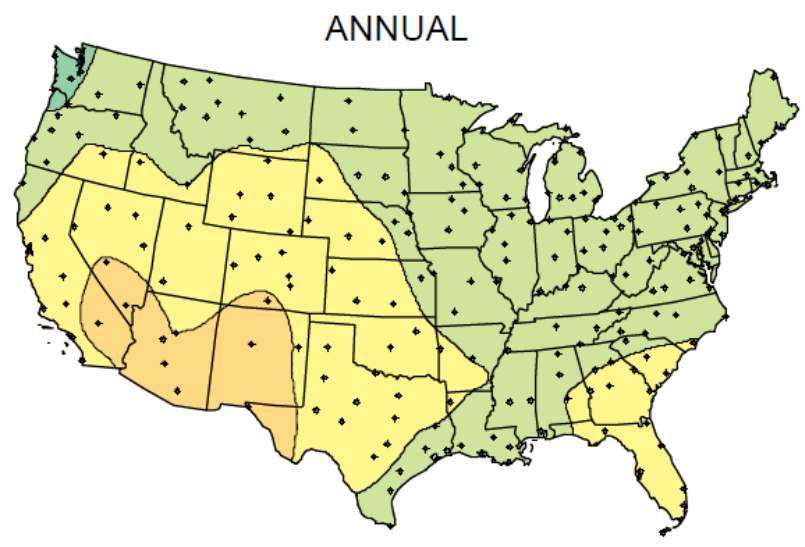

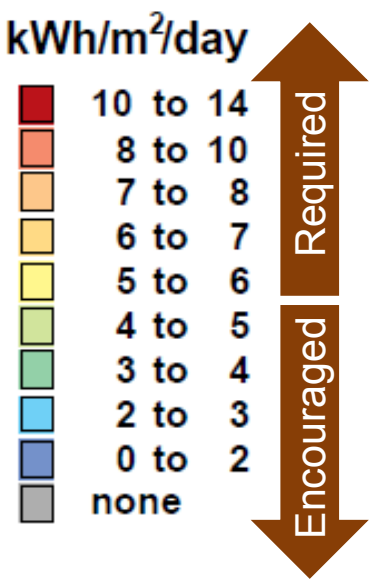

c. Location does not have significant natural shading (e.g., trees, tall buildings on the south-facing roof).

d. Home as designed has adequate free roof area within $+/-45^{\circ}$ of true south as noted in the table below. Note that in some cases a house may have insufficient roof area for the Solar Electric RERH checklist, but it may still have the minimum roof area for the Solar Thermal RERH checklist, and would therefore have to comply with the Solar Thermal RERH checklist. In other cases, the home may only have adequate south facing roof for the Solar Electric or Solar Thermal RERH checklist, but not both. In that case, the builder can decide which one of those two checklists to apply.

\begin{tabular}{|c|c|c|}
\hline $\begin{array}{c}\text { Conditioned Floor Area of } \\
\text { House (ft }\end{array}$ & $\begin{array}{c}\text { Minimum Roof Area for } \\
\text { Solar Electric RERH } \\
\text { Checklist }\left(\mathrm{ft}^{2}\right)\end{array}$ & $\begin{array}{c}\text { Minimum Roof Area for } \\
\text { Solar Thermal RERH } \\
\text { Checklist }\left(\mathrm{ft}^{2}\right)\end{array}$ \\
\hline$\leq 2000$ & 110 & 40 \\
\hline$\leq 4000$ & 220 & 60 \\
\hline$\leq 6000$ & 330 & 80 \\
\hline$>6000$ & 440 & 100 \\
\hline
\end{tabular}

20 The following Map is shown to depict climate zone boundaries. It is for illustrative purposes only and is based on the 2012 IECC. 


\section{IECC Climate Zone Map}

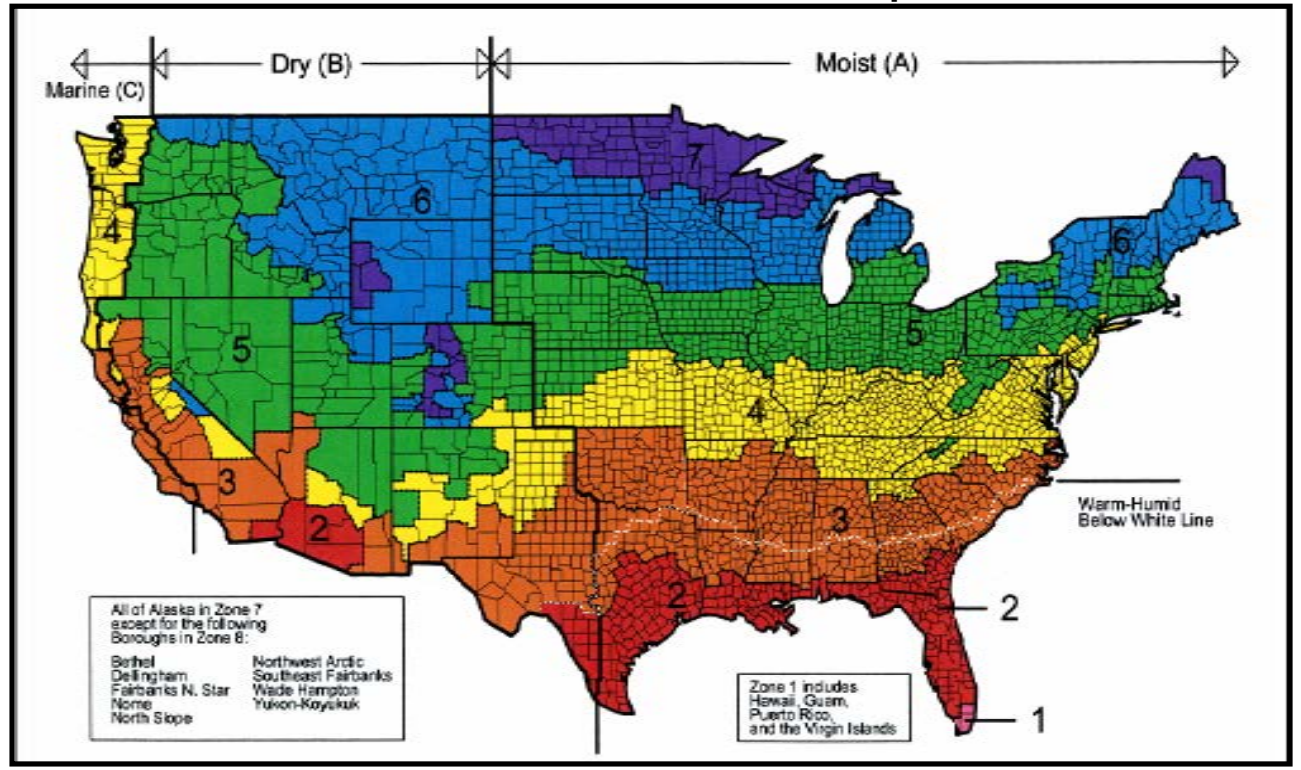

${ }^{21}$ HVAC System Type for the Target Home shall be the same as the Rated Home, with the following exceptions. The Target Home shall be configured with an air-source heat pump in Climate Zones 1-6 when the Rated Home is modeled with a ground-source heat pump, electric strip or baseboard heat; and the Target Home shall be configured with groundsource heat pump in Climate Zones $7 \& 8$ when the Rated Home is modeled with an air-source or ground-source heat pump, electric strip or baseboard heat. Applicable efficiency levels shall be selected from Exhibit 2.

22 DOE recommends, but does not require, that cooling systems in hot/humid climates utilize controls for immediate blower shutoff after condenser shutoff, to prevent re-evaporation of moisture off the wet coil.

${ }^{23}$ Air source heat pumps with electric resistance backup cannot be used in homes qualified in Climate Zones 7 \& 8 using the Prescriptive Path.

${ }^{24}$ Envelope leakage shall be determined by an approved verifier using a RESNET-approved testing protocol.

${ }^{25}$ All decorative glass and skylight window areas count toward the total window area to above-grade conditioned floor area (WFA) ratio.

${ }^{26}$ DOE strongly encourages all DOE Zero Energy Ready Home partners to consider using R-5 windows in cold climates in anticipation of them becoming the state-of-the-art window choice in the near future. Visit the DOE web site (http://www1.eere.energy.gov/buildings/windowsvolumepurchase/) for more details and sources of these windows.

${ }^{27}$ For homes using Exhibit 2 for Prescriptive compliance with the DOE Zero Energy Ready Home, the following exceptions to the U-Value and SHGC requirements in Exhibit 2 apply:

a. An area-weighted average of fenestration products shall be permitted to satisfy the U-factor requirements; 


\section{DOE Zero Energy Ready Home National Program Requirements (Rev. 04) April 21, 2014}

b. An area-weighted average of fenestration products $\geq 50 \%$ glazed shall be permitted to satisfy the SHGC requirements;

c. 15 square feet of glazed fenestration per dwelling unit shall be exempt from the U-factor and SHGC requirements, and shall be excluded from area-weighted averages calculated using a) and b), above;

d. One side-hinged opaque door assembly up to 24 square feet in area shall be exempt from the U-factor requirements and shall be excluded from area-weighted averages calculated using a) and b), above;

e. Fenestration utilized as part of a passive solar design shall be exempt from the $U$-factor and SHGC requirements, and shall be excluded from area-weighted averages calculated using a) and b), above. Exempt windows shall be facing within 45 degrees of true South and directly coupled to thermal storage mass that has a heat capacity $>20$ $\mathrm{btu} / \mathrm{ft}^{3} \mathrm{x}^{\circ} \mathrm{F}$ and provided in a ratio of at least 3 sq. $\mathrm{ft}$. per sq. $\mathrm{ft}$. of South facing fenestration. Generally, thermal mass materials will be at least 2 in. thick.

28

For Prescriptive Path: All decorative glass and skylight window areas count toward the total window area to abovegrade conditioned floor area (WFA) ratio. For homes using the Prescriptive Path that have a WFA ratio $>15 \%$, the following additional requirements apply:

a. In Climate Zones 1, 2, and 3, an improved window SHGC is required and is determined by:

Improved SHGC $=$ [0.15 / WFA] x [ENERGY STAR SHGC]

Where the ENERGY STAR SHGC is the maximum allowable SHGC in Exhibit 1, ENERGY STAR Reference Design, for the Climate Zone where the home will be built.

b. In Climate Zones 4, 5, 6, 7, and 8, an improved window U-Value is required and is determined by:

Improved U-Value $=[0.15 /$ WFA] $x$ [ENERGY STAR U-Value $]$

Where the ENERGY STAR U-Value is the maximum allowable U-Value in Exhibit 1, ENERGY STAR Reference Design, for the Climate Zone where the home will be built.

${ }^{29}$ In homes with heat pumps, programmable thermostats shall have "Adaptive Recovery" technology to prevent the excessive use of electric back-up heating.

30 The average-size home for a specific number of bedrooms is termed "Benchmark Home". The conditioned floor area for a Benchmark Home (CFA Benchmark Home) is determined by selecting the appropriate value from Exhibit 3 . For homes with more than 8 bedrooms, the CFA Benchmark Home shall be determined by multiplying $600 \mathrm{sq}$. ft. times the total number of bedrooms and adding 400 sq. ft.

Example 10 Bedroom Home: Benchmark Home $=(600$ sq. ft. $x 10)+400$ sq. ft. $=6,400$ sq. ft.

Effective for Homes

Permitted Starting 6/21/2014
Revised April 21, 2014

Page 9 of 9 


\section{Appendix C: Example Zero Energy Ready Home Scorecard}




\section{Template for the Stapleton Zero Energy Ready Home Audit 2014}

\section{ENERGY STAR for Home Baseline}

\section{ENERGY STAR Qualified Homes Version 3}

The following checklists shall be permitted to be completed for a batch of homes using a RESNET-approved sampling protocol. Sampling is not permitted for the HVAC System Quality Installation Contractor Checklist.

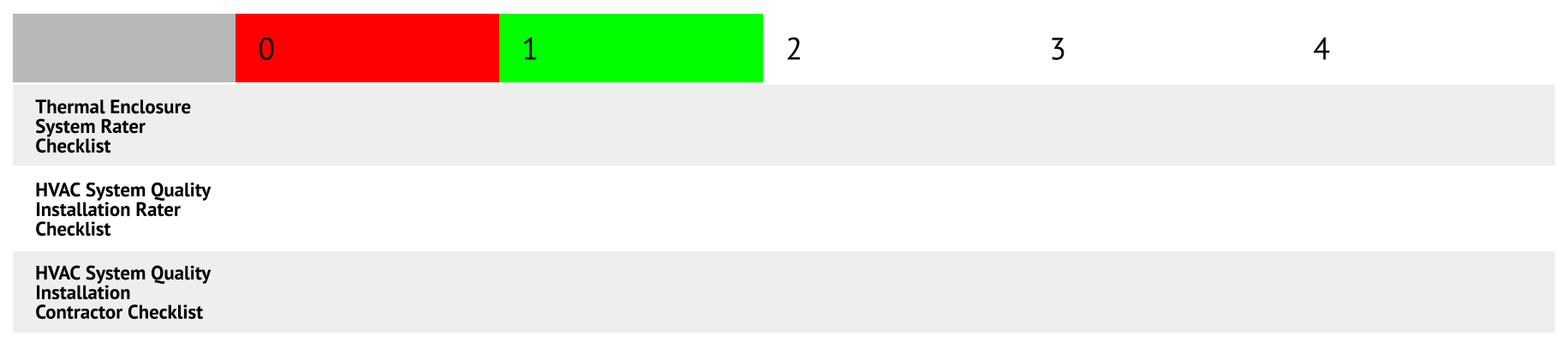

\section{Envelope}

\section{Fenestration}

Windows shall meet the ENERGY STAR Window Product Criteria which are in force at the time of project permitting. For homes achieving PHIUS+ certification where triple glazed window assemblies with thermal breaks/spacers between the panes are used, such windows are deemed to meet this requirement even in the absence of an ENERGY STAR certification. One side-hinged opaque door assembly up to 24 square feet in area shall be exempt from the $\mathrm{U}$-factor requirements and shall be excluded from area-weighted averages calculated using a) and b), above; Fenestration utilized as part of a passive solar design shall be exempt from the U-factor and SHGC requirements, and shall be excluded from area-weighted averages calculated using a) and b), above. Exempt windows shall be facing within 45 degrees of true South and directly coupled to thermal storage mass that has a heat capacity $>20$ $\mathrm{btu} / \mathrm{ft3} \times \circ \mathrm{F}$ and provided in a ratio of at least 3 sq. $\mathrm{ft}$. per sq. $\mathrm{ft}$. of South facing fenestration. Generally, thermal mass materials will be at least 2 in. thick.

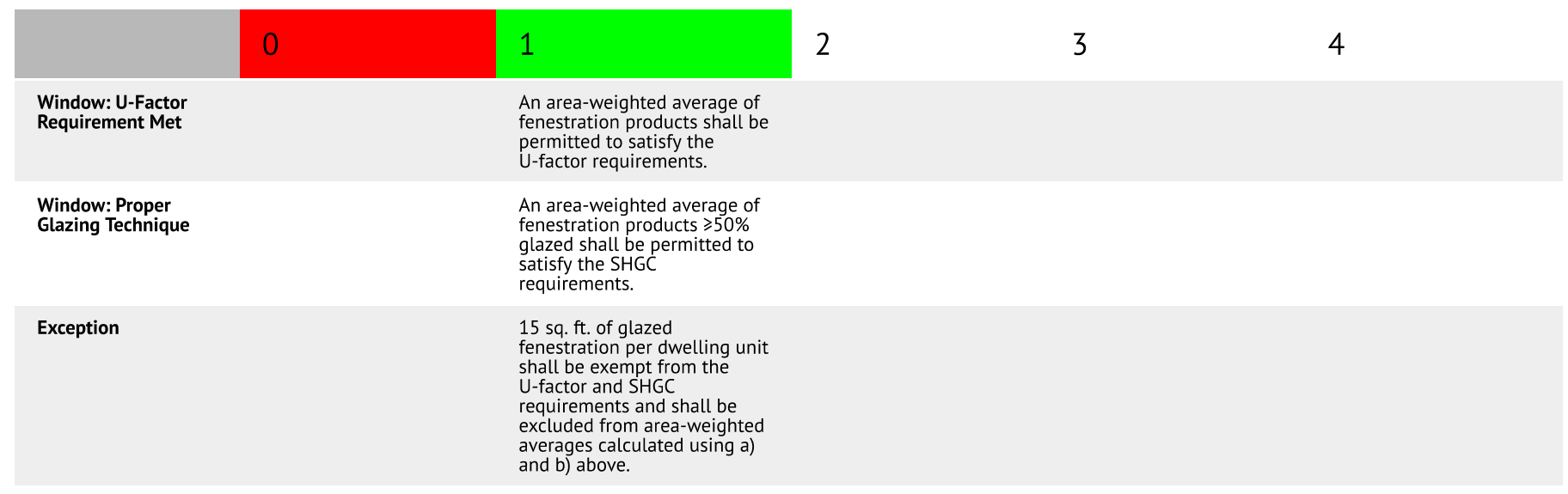

\section{Ceiling}

Insulation levels in a home shall meet or exceed the component insulation requirements in the 2012 International Energy Conservation Code (IECC). 


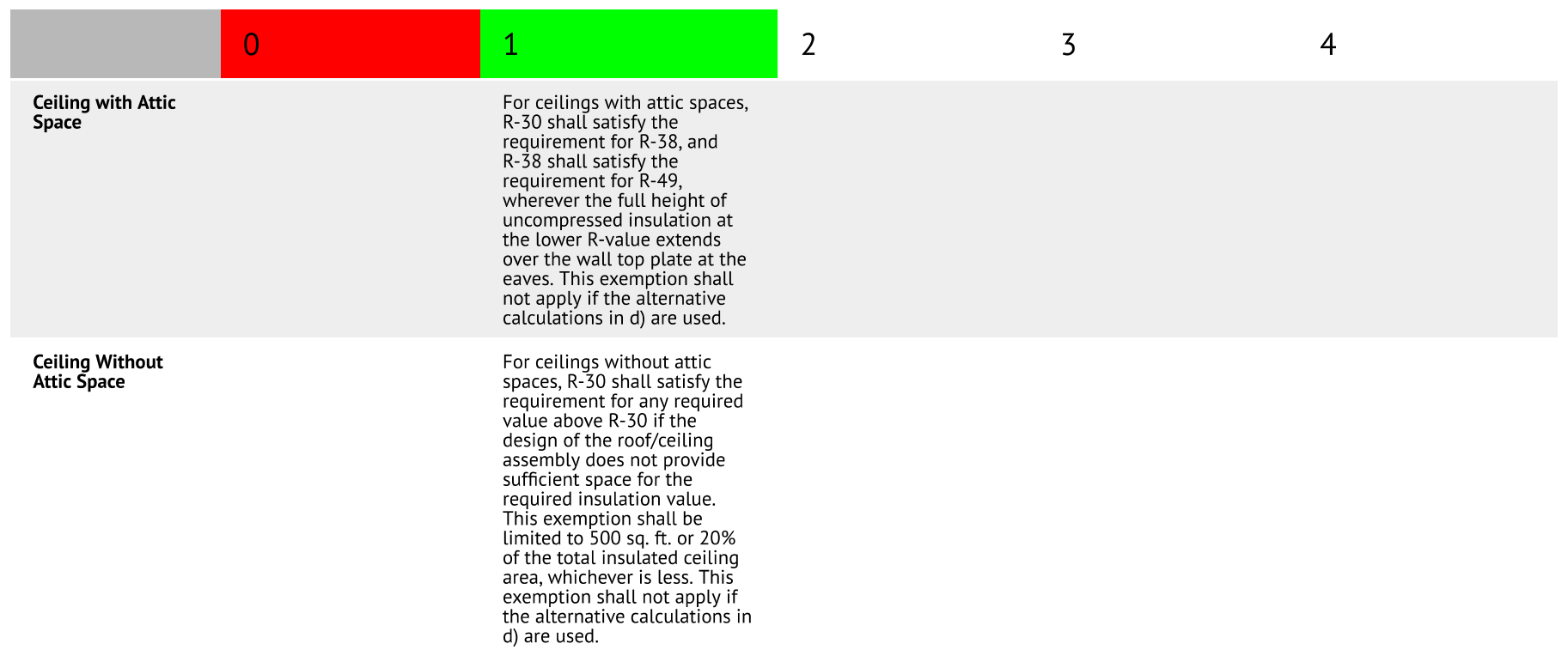

\section{Wall Assembly}

Insulation levels in a home shall meet or exceed the component insulation requirements in the 2012 International Energy Conservation Code (IECC).

\begin{tabular}{|l|l|l|l|l} 
& 0 & 1 & 2 & 3 \\
\hline $\begin{array}{l}\text { Proper Wall } \\
\text { Insulation Used }\end{array}$ & & 1 & 4 & 4 \\
\hline
\end{tabular}

\section{Floor Assembly}

Insulation levels in a home shall meet or exceed the component insulation requirements in the 2012 International Energy Conservation Code (IECC).

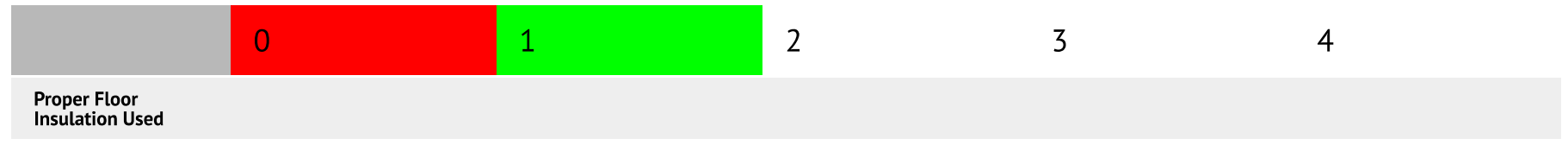

\section{Concrete Slab/Foundation Used}

Insulation levels in a home shall meet or exceed the component insulation requirements in the 2012 International Energy Conservation Code (IECC).

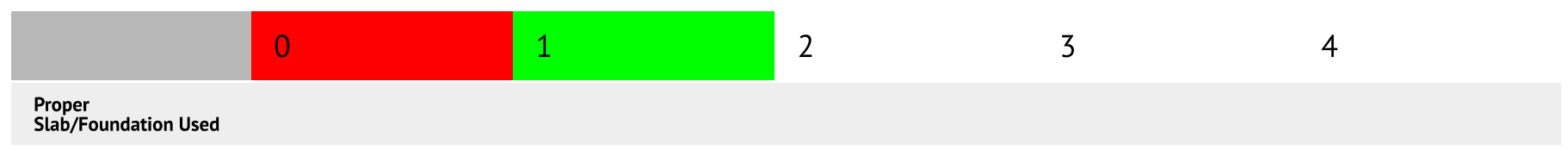

\section{Water Management System}

\section{Water-Managed Site and Foundation}

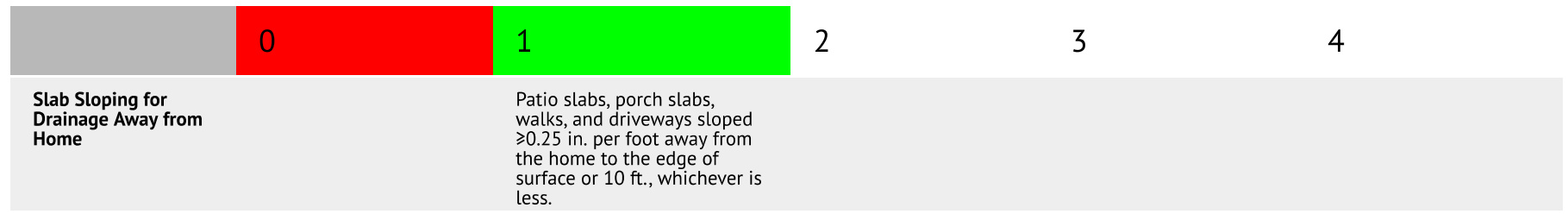




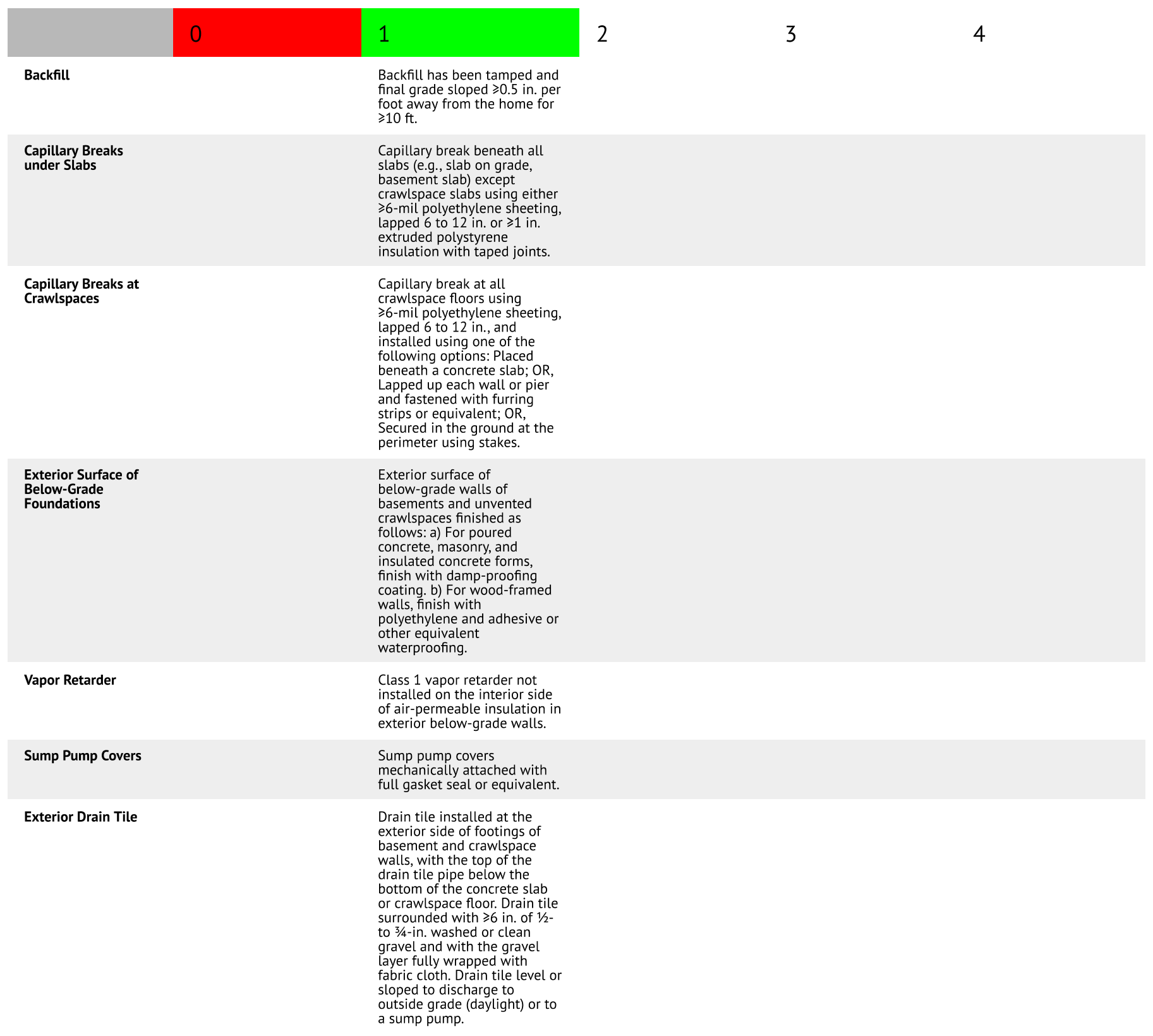

\section{Water-Managed Wall Assembly}

\begin{tabular}{|c|c|c|c|c|}
\hline & 1 & 2 & 3 & 4 \\
\hline $\begin{array}{l}\text { Flashing for Masonry } \\
\text { and Stucco Walls }\end{array}$ & $\begin{array}{l}\text { Flashing at the bottom of } \\
\text { exterior walls with weep } \\
\text { holes included for masonry } \\
\text { veneer and weep screed for } \\
\text { stucco cladding systems, or } \\
\text { equivalent drainage system. }\end{array}$ & & & \\
\hline $\begin{array}{l}\text { Drainage Plane and } \\
\text { Penetrations Sealing }\end{array}$ & $\begin{array}{l}\text { Fully sealed continuous } \\
\text { drainage plane behind } \\
\text { exterior cladding that laps } \\
\text { over flashing in Item } 2.1 \text { and } \\
\text { fully sealed at all } \\
\text { penetrations. Additional } \\
\text { bond-break drainage plane } \\
\text { layer provided behind all } \\
\text { stucco and nonstructural } \\
\text { masonry cladding wall } \\
\text { assemblies. }\end{array}$ & & & \\
\hline Flashing at Openings & $\begin{array}{l}\text { Window and door openings } \\
\text { fully flashed. }\end{array}$ & & & \\
\hline
\end{tabular}

\section{Water-Managed Roof Assembly}




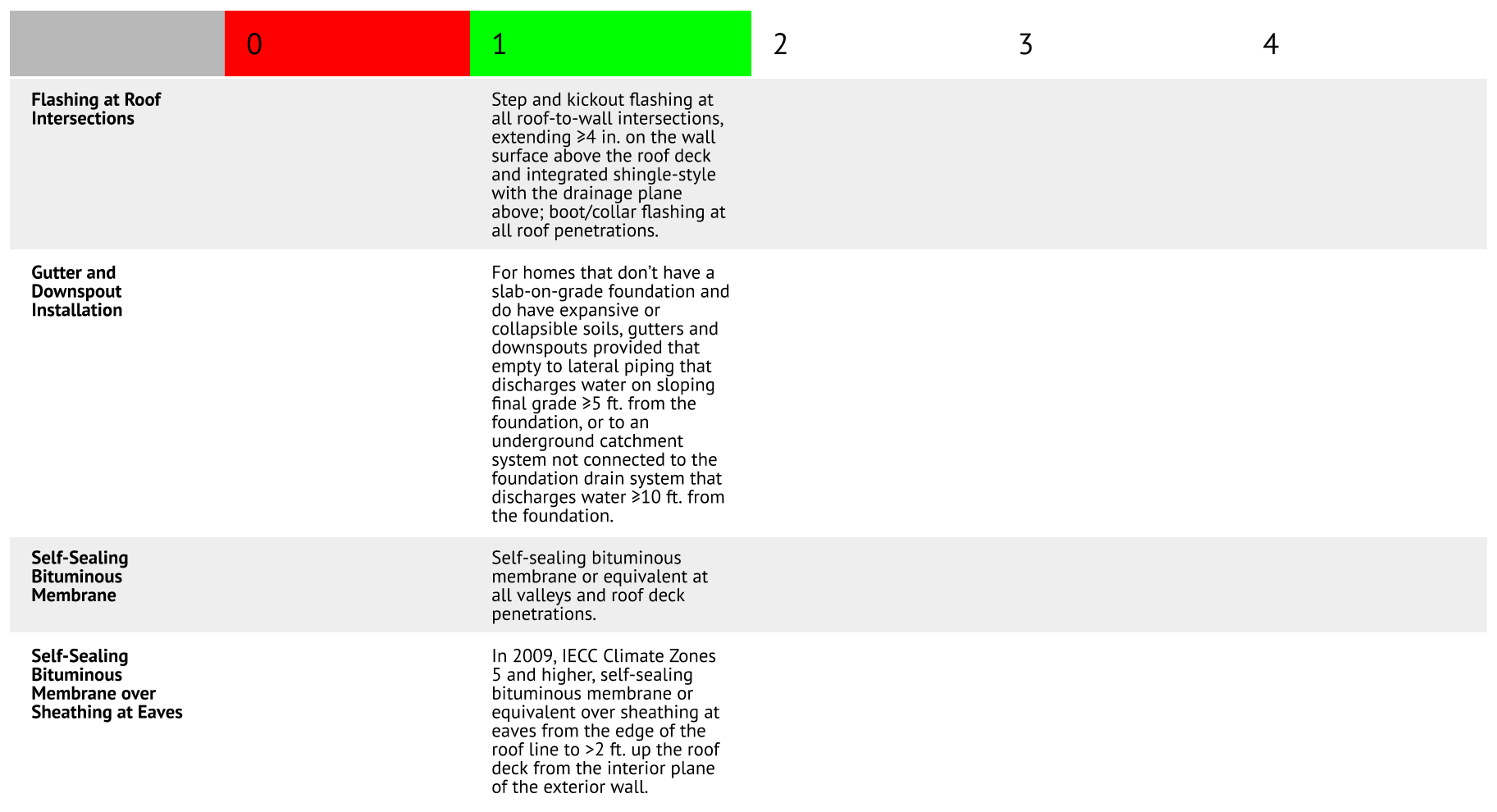

\section{Water-Managed Building Materials}

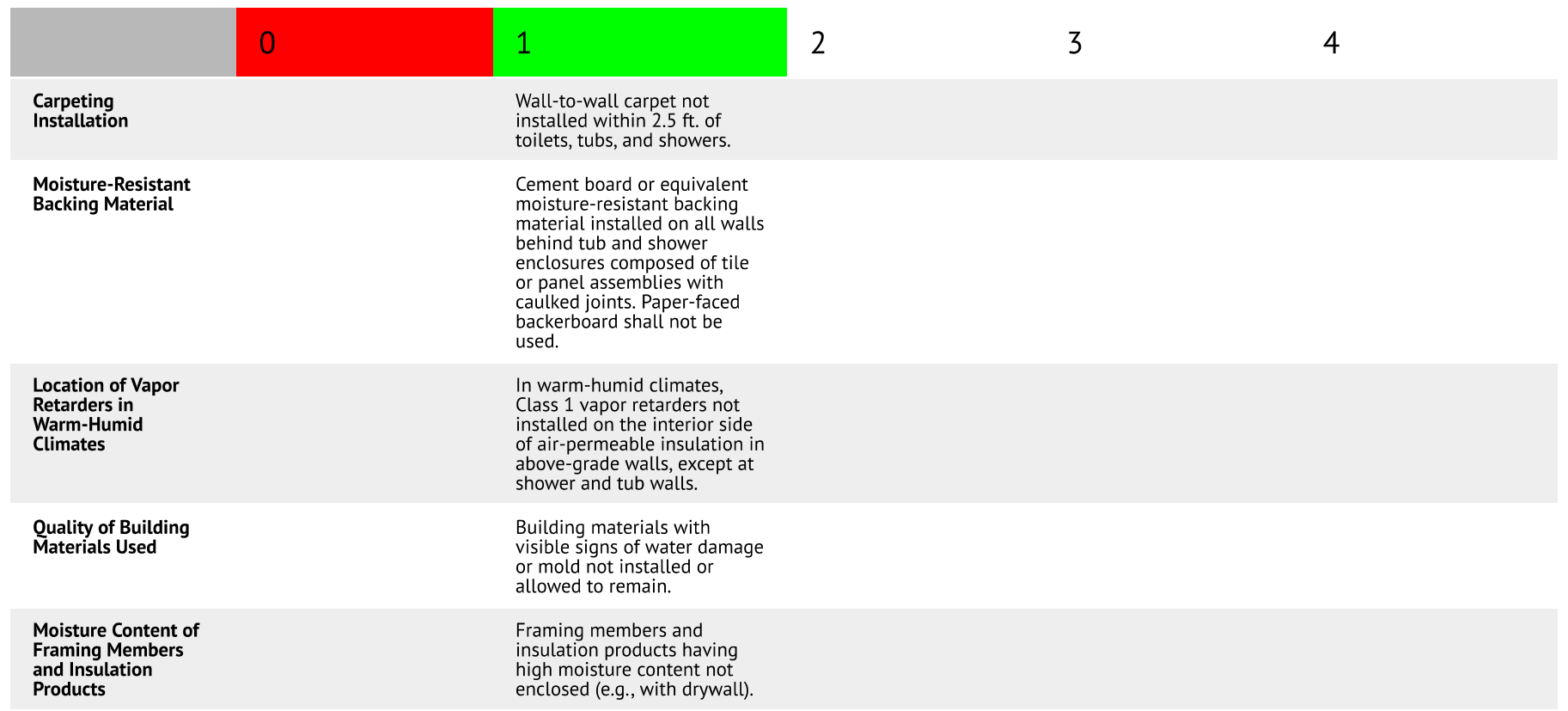

\section{Duct System}

\section{Duct Location}

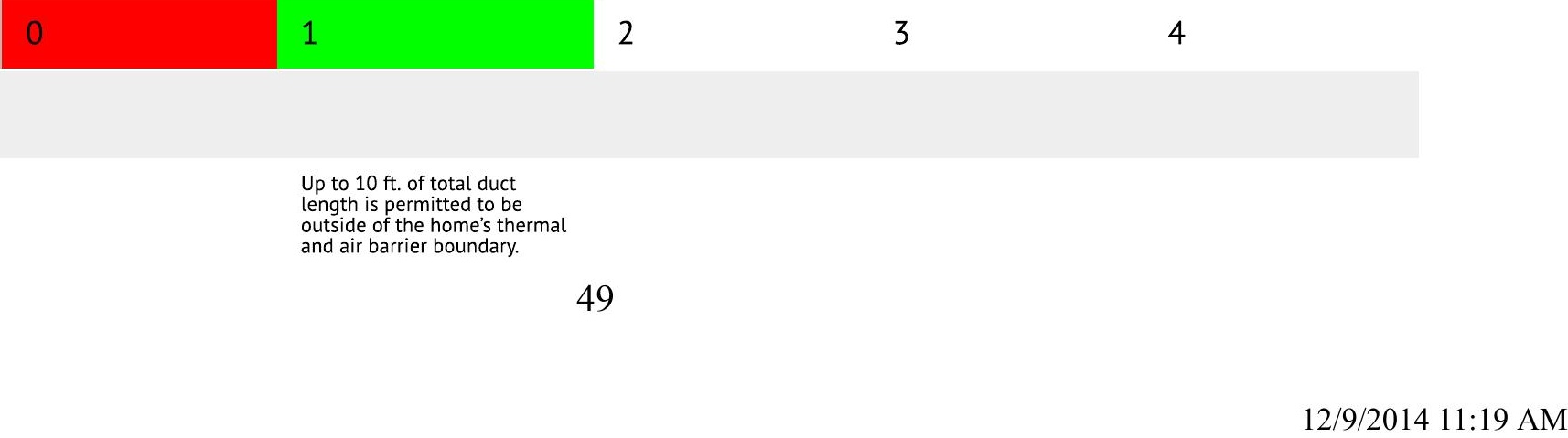

In 2009, IECC Climate Zone bituminous membrane eaves from the edge of the deck from the interior plane of the exterior wall. 


\begin{tabular}{|l|l|}
\hline Exception 2 & 1 \\
\hline Exception 3 & $\begin{array}{l}\text { Ducts are located in an } \\
\text { unvented attic, regardless of } \\
\text { whether this space is } \\
\text { conditioned with a supply } \\
\text { register. }\end{array}$ \\
\hline Exception 4 & $\begin{array}{l}\text { Ducts are located in a vented } \\
\text { attic with characteristics } \\
\text { pertaining to climate zone } \\
\text { (see Zero Energy Ready Home } \\
\text { requirements). }\end{array}$ \\
\hline Exception 5 & $\begin{array}{l}\text { Jump ducts that do not } \\
\text { directly deliver conditioned } \\
\text { air from the HVAC unit may } \\
\text { be located in attics if all } \\
\text { joints, including boot to } \\
\text { drywall, are fully air sealed } \\
\text { with mastic or foam, and the } \\
\text { jump duct is fully buried } \\
\text { under the attic insulation. }\end{array}$ \\
\hline Exception 6 & $\begin{array}{l}\text { Ducts are located within an } \\
\text { unvented crawlspace. }\end{array}$ \\
\hline Exception 7 & $\begin{array}{l}\text { Ducts are located in a } \\
\text { basement that is within the } \\
\text { homes thermal boundary. }\end{array}$ \\
\hline
\end{tabular}

\section{Water Efficiency}

\section{Hot Water Delivery System Shall Meet Efficient Design Requirements}

\begin{tabular}{|l|l|}
\hline & 1 \\
\hline Hot Water Delivery & 1 \\
\hline System & To minimize water wasted \\
& while waiting for hot water, \\
the hot water distribution & system shall store no more \\
that 0.5 gallon of water in any & piping/manifold between the \\
hot water source and any hot \\
water fixture.
\end{tabular}




\section{Lighting and Appliances}

\section{Appliances}

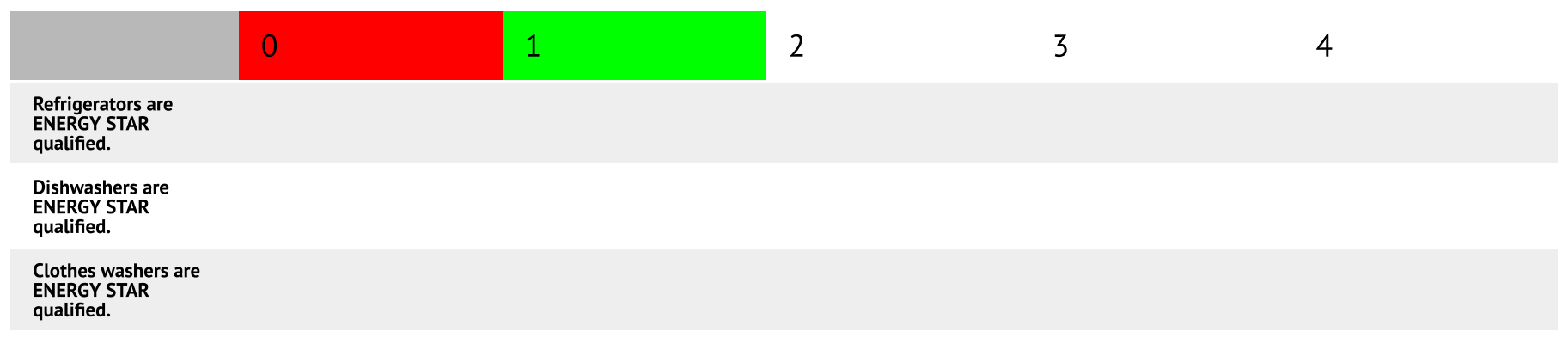

\section{Lighting}

ONE of the following is required. Submit $n / a$ for the other

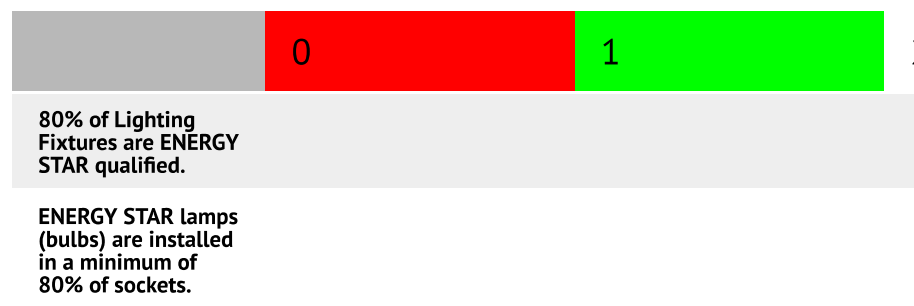

2

3

4

\section{Fans}

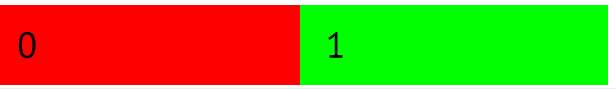

2

3

4

All installed

bathroom ventilation

units are ENERG

STAR qualified.

All installed ceiling

fans are ENERGY
STAR qualified.

\section{Indoor Air Quality}

\section{EPA Indoor airPLUS}

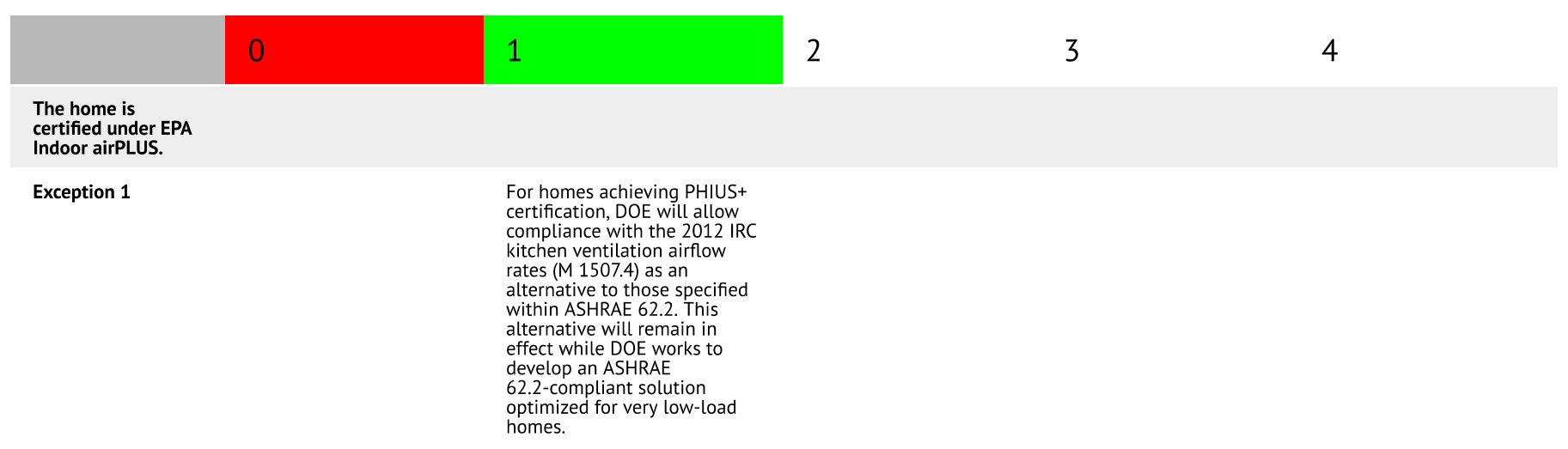

\section{Renewable Ready}

Consolidated Renewable Energy Ready Home (RERH) 


\begin{tabular}{|c|c|c|c|c|}
\hline & 1 & 2 & 3 & 4 \\
\hline \multicolumn{2}{|l|}{$\begin{array}{l}\text { Renewable Energy } \\
\text { Ready Home (RERH) } \\
\text { Consolidated } \\
\text { Checklist }\end{array}$} & & & \\
\hline Condition 1 & $\begin{array}{l}\text { If a solar photovoltaic or solar } \\
\text { hot water system is already } \\
\text { included with the home, then } \\
\text { compliance with the photovoltaic } \\
\text { or solar hot water RERH checklist } \\
\text { is not required. }\end{array}$ & & & \\
\hline Condition 2 & $\begin{array}{l}\text { Location, based on zip code, has } \\
\text { at least } 5 \mathrm{~kW} / \mathrm{m} 2 / \text { day average } \\
\text { daily solar radiation based on } \\
\text { annual solar insolation using this } \\
\text { online tool: } \\
\text { http://pvwatts.nrel.gov/. }\end{array}$ & & & \\
\hline Condition 3 & $\begin{array}{l}\text { Location does not have } \\
\text { significant natural shading (e.g., } \\
\text { trees, tall buildings on the south- } \\
\text { facing roof). }\end{array}$ & & & \\
\hline Condition 4 & $\begin{array}{l}\text { Home as designed has adequate } \\
\text { free roof area within } \pm 45^{\circ} \text { of } \\
\text { true south as noted in the table } \\
\text { below. Note that in some cases, a } \\
\text { house may have insufficient roof } \\
\text { area for the Solar Electric RERH } \\
\text { checklist, but it may still have } \\
\text { the minimum roof area for the } \\
\text { Solar Thermal RERH checklist } \\
\text { and therefore would have to } \\
\text { comply with the Solar Thermal } \\
\text { RERH checklist. In other cases, } \\
\text { the home may have only } \\
\text { adequate south-facing roof for } \\
\text { the Solar Electric or Solar } \\
\text { Thermal RERH checklist but not } \\
\text { both. }\end{array}$ & & & \\
\hline
\end{tabular}

Location, based on zip code, has daily solar radiation based on annual solar insolation using this

cation does not have (e.g. facing roof). ( checklist, but ir Electric RERH both.

Renewable Energy

Consolidated included with the home, then

his checklist applies only unde \\ http://perform.ibacos.com/example-builder/assess}

2

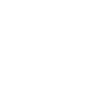


